Prepared in cooperation with

New York State Department of Environmental Conservation

\title{
Groundwater Quality in the Upper Susquehanna River Basin, New York, 2009
}

Open-File Report 2012-1045

U.S. Department of the Interior U.S. Geological Survey 
Cover. Morning mist along East Branch Owego Creek valley, near Hamlet of Berkshire, Tioga County. 


\section{Groundwater Quality in the Upper Susquehanna River Basin, New York, 2009}

By James E. Reddy and Amy J. Risen

Prepared in cooperation with

New York State Department of Environmental Conservation

Open-File Report 2012-1045

U.S. Department of the Interior

U.S. Geological Survey 


\title{
U.S. Department of the Interior \\ KEN SALAZAR, Secretary \\ U.S. Geological Survey \\ Marcia K. McNutt, Director
}

\author{
U.S. Geological Survey, Reston, Virginia: 2012
}

For more information on the USGS - the Federal source for science about the Earth, its natural and living resources, natural hazards, and the environment, visit http://www.usgs.gov or call 1-888-ASK-USGS.

For an overview of USGS information products, including maps, imagery, and publications, visit http://www.usgs.gov/pubprod

To order this and other USGS information products, visit http://store.usgs.gov

Any use of trade, product, or firm names is for descriptive purposes only and does not imply endorsement by the U.S. Government.

Although this report is in the public domain, permission must be secured from the individual copyright owners to reproduce any copyrighted materials contained within this report.

Suggested citation:

Reddy, J.E., and Risen, A.J., 2012, Groundwater quality in the Upper Susquehanna River Basin, New York, 2009: U.S. Geological Survey Open-File Report 2012-1045, 30 p., at http://pubs.usgs.gov/of/2012/1045/. 


\section{Contents}

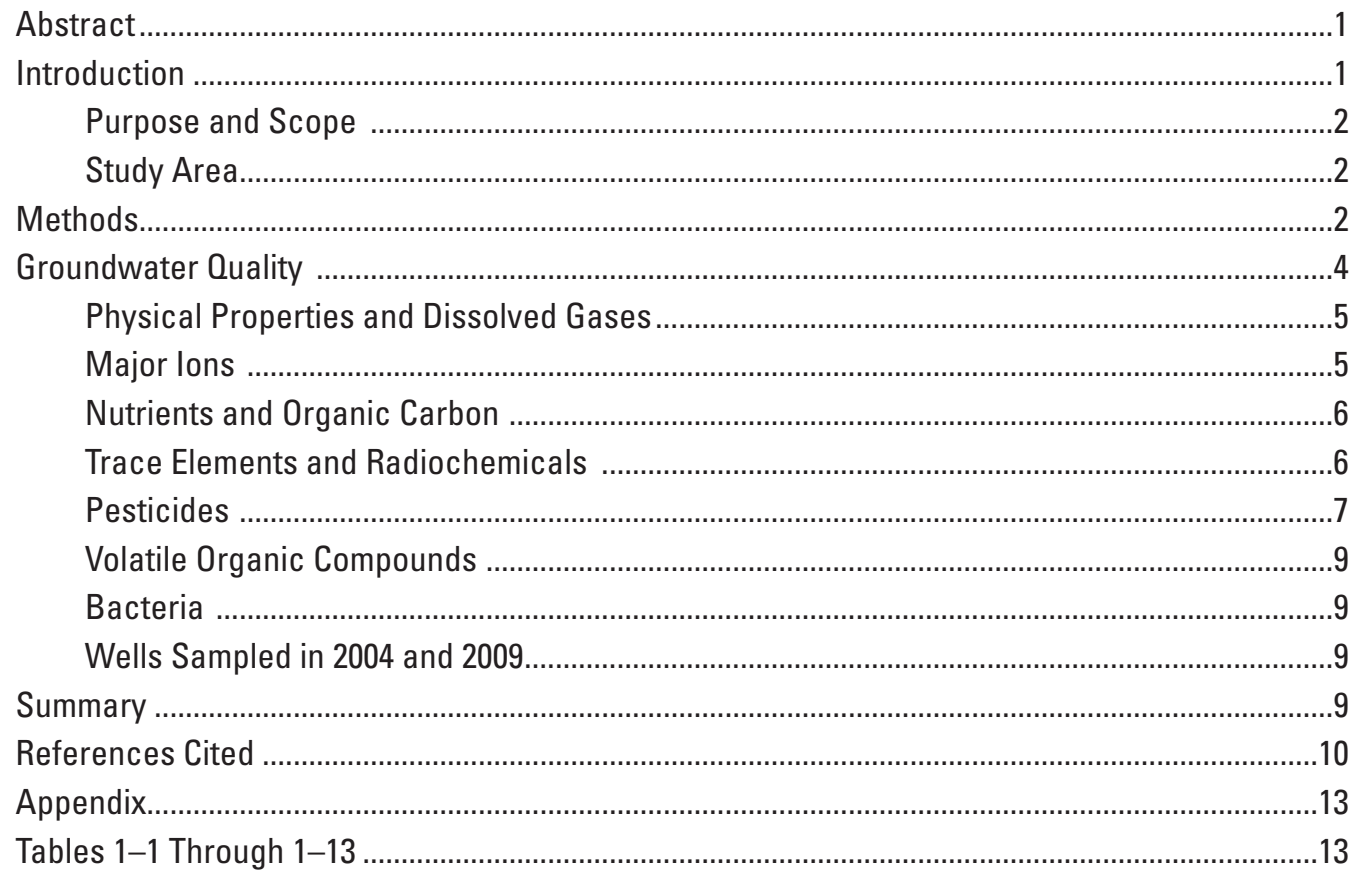

\section{Figures}

1. Map showing pertinent geographic features of study area in the Upper Susquehanna River Basin, New York, and locations of the 30 wells sampled in 2009. (Well data are provided in table 1-1, at end of report.).

\section{Tables}

1. Previous groundwater-quality studies and reports

2. Summary statistics for concentrations of major ions in sand and gravel aquifers and bedrock aquifers in the Upper Susquehanna River Basin, New York, 2009.

3. Summary statistics for concentrations of nutrients and organic carbon in sand and gravel aquifers and bedrock aquifers in the Upper Susquehanna River Basin, New York, 2009

4. Summary statistics for concentrations of trace elements and radiochemicals in sand and gravel aquifers and bedrock aquifers in the Upper Susquehanna River Basin, New York, 2009

1-1. Information on wells sampled in the Upper Susquehanna River Basin, New York, 2009

1-2. Compounds for which groundwater samples from the Upper Susquehanna River Basin, New York were analyzed but not detected, 2009. -Continued..

1-3. Physical properties of groundwater samples from the Upper Susquehanna River Basin, New York, 2009.

1-4. Concentrations of major ions in groundwater samples from the Upper Susquehanna River Basin, New York, 2009 
1-5. Concentrations of nutrients and total organic carbon in groundwater samples from the Upper Susquehanna River Basin, New York, 2009.

1-6. Concentrations of trace elements and radiochemicals in groundwater samples from the Upper Susquehanna River Basin, New York, 2009.

1-7. Concentrations of pesticides detected in groundwater samples from the Upper Susquehanna River Basin, New York, 2009.

1-8. Concentrations of volatile organic compounds in groundwater samples from the Upper Susquehanna River Basin, New York, 2009

1-9. Concentrations of bacteria in unfiltered groundwater samples from the Upper Susquehanna River Basin, New York, 2009

1-10. Physical properties of and concentrations of major ions, nutrients and total organic carbon, and bacteria in groundwater samples collected in the Upper Susquehanna River Basin, New York, 2004 and 2009

1-11. Concentrations of trace elements and radiochemicals in groundwater samples collected in the Upper Susquehanna River Basin, New York, 2004 and 2009

1-12. Concentrations of pesticides in groundwater samples collected in the Upper Susquehanna River Basin, New York, 2004 and 2009.

1-13. Concentrations of volatile organic compounds in groundwater samples collected in the Upper Susquehanna River Basin, New York, 2004 and 2009 


\section{Conversion Factors}

Inch/Pound to SI

\begin{tabular}{lll}
\hline \multicolumn{1}{c}{ Multiply } & By & To obtain \\
\hline inch (in.) & \multicolumn{2}{c}{ Length } \\
foot (ft) & 0.3048 & centimeter $(\mathrm{cm})$ \\
\hline \multicolumn{3}{c}{ Area } \\
\hline square mile $\left(\mathrm{mi}^{2}\right)$ & 2.590 & square kilometer $\left(\mathrm{km}^{2}\right)$ \\
\hline \multicolumn{3}{c}{ Volume } \\
\hline million gallons (Mgal) & 3,785 & \multicolumn{3}{c}{ cubic meter $\left(\mathrm{m}^{3}\right)$} \\
\hline \multicolumn{3}{c}{ Flow rate } \\
\hline gallon per minute (gal/min) & 0.06309 & liter per second $(\mathrm{L} / \mathrm{s})$ \\
gallon per day (gal/d) & 0.003785 & cubic meter per day $\left(\mathrm{m}^{3} / \mathrm{d}\right)$ \\
million gallons per day (Mgal/d) & 0.04381 & cubic meter per second $\left(\mathrm{m}^{3} / \mathrm{s}\right)$ \\
inch per year (in/yr) & 25.4 & millimeter per year $(\mathrm{mm} / \mathrm{yr})$ \\
\hline
\end{tabular}

Temperature in degrees Celsius $\left({ }^{\circ} \mathrm{C}\right)$ may be converted to degrees Fahrenheit $\left({ }^{\circ} \mathrm{F}\right)$ as follows:

$$
{ }^{\circ} \mathrm{F}=\left(1.8 \times{ }^{\circ} \mathrm{C}\right)+32
$$

Temperature in degrees Fahrenheit $\left({ }^{\circ} \mathrm{F}\right)$ may be converted to degrees Celsius $\left({ }^{\circ} \mathrm{C}\right)$ as follows:

$$
{ }^{\circ} \mathrm{C}=\left({ }^{\circ} \mathrm{F}-32\right) / 1.8
$$

Vertical coordinate information is referenced to the National Geodetic Vertical Datum of 1929 (NGVD 29).

Horizontal coordinate information is referenced to the insert North American Datum of 1983 (NAD 83).

Specific conductance is given in microsiemens per centimeter at 25 degrees Celsius $(\mu \mathrm{S} / \mathrm{cm}$ at $\left.25^{\circ} \mathrm{C}\right)$.

Concentrations of chemical constituents in water are given either in milligrams per liter ( $\mathrm{mg} / \mathrm{L})$ or micrograms per liter ( $\mu \mathrm{g} / \mathrm{L})$.

Laboratory reporting level (LRL) - Generally equal to twice the yearly determined long-term method detection level (LT-MDL). The LRL controls false negative error. The probability of falsely reporting a nondetection for a sample that contained an analyte at a concentration equal to or greater than the LRL is predicted to be less than or equal to 1 percent. The value of the LRL will be reported with a "less than" remark code for samples in which the analyte was not detected. The National Water Quality Laboratory collects quality-control data from selected analytical methods on a continuing basis to determine LT-MDLs and to establish LRLs. These values are reevaluated annually based on the most current quality-control data, and, therefore, may change (Childress and others, 1999). 


\section{Abbreviations}

$\begin{array}{ll}\text { AMCL } & \text { Alternative maximum contaminant level } \\ \text { CFCL } & \text { USGS Chlorofluorocarbon Laboratory } \\ \text { CFU/mL } & \text { Colony forming units per milliliter } \\ \text { CIAT } & \text { 2-Chloro-4-isopropylamino-6-amino-s-triazine (also called deethylatrazine) } \\ \text { cICP-MS } & \text { Collision/reaction cell inductively coupled plasma-mass spectrometry } \\ \text { ESA } & \text { Ethanesulfonic acid } \\ \text { GC-MS } & \text { Gas chromatography-mass spectrometry } \\ \text { HA } & \text { Health Advisory for drinking water } \\ \text { HPC } & \text { Heterotrophic plate count } \\ \text { HPLC-MS } & \text { High-performance liquid chromatography-mass spectrometry } \\ \text { ICP-AES } & \text { Inductively coupled plasma-atomic emission spectrometry } \\ \text { ICP-MS } & \text { Inductively coupled plasma-mass spectrometry } \\ \text { ICP-OES } & \text { Inductively coupled plasma-optical emission spectrometry } \\ \text { LRL } & \text { Laboratory Reporting Level } \\ \text { MCL } & \text { Maximum Contaminant Level } \\ \text { NWOL } & \text { USGS National Water Quality Laboratory } \\ \text { NYSDEC } & \text { New York State Department of Environmental Conservation } \\ \text { NYSDOH } & \text { New York State Department of Health } \\ \text { OIET } & \text { 2-Hydroxy-4-isopropylamino-6-ethylamino-s-triazine (also called } \\ \text { hydroxyatrazine) } & \\ \text { SMCL } & \text { Secondary Maximum Contaminant Level } \\ \text { USEPA } & \text { U.S. Environmental Protection Agency } \\ \text { USGS } & \text { U.S. Geological Survey } \\ \text { VOC } & \text { Volatile organic compound } \\ & \\ \text { ICP } & \end{array}$

Other abbreviations in this report:

micrometer $(\mu \mathrm{m})$

micrograms per liter $(\mu \mathrm{g} / \mathrm{L})$

milligrams per liter (mg/L)

microsiemens per centimeter $(\mu \mathrm{S} / \mathrm{cm})$

platinum-cobalt units (Pt-Co units)

picocuries per liter ( $\mathrm{pCi} / \mathrm{L})$ 


\title{
Groundwater Quality in the Upper Susquehanna River Basin, New York, 2009
}

\author{
By James E. Reddy and Amy J. Risen
}

\begin{abstract}
Water samples were collected from 16 production wells and 14 private residential wells in the Upper Susquehanna River Basin from August through December 2009 and were analyzed to characterize the groundwater quality in the basin. Wells at 16 of the sites were completed in sand and gravel aquifers, and 14 were finished in bedrock aquifers. In 2004-2005, six of these wells were sampled in the first Upper Susquehanna River Basin study. Water samples from the 2009 study were analyzed for 10 physical properties and 137 constituents that included nutrients, organic carbon, major inorganic ions, trace elements, radionuclides, pesticides, volatile organic compounds, and 4 types of bacterial analyses. Results of the water-quality analyses are presented in tabular form for individual wells, and summary statistics for specific constituents are presented by aquifer type. The results are compared with Federal and New York State drinking-water standards, which typically are identical. The results indicate that groundwater genrally is of acceptable quality, although concentrations of some constituents exceeded at least one drinking-water standard at 28 of the 30 wells. These constituents include: $\mathrm{pH}$, sodium, aluminum, manganese, iron, arsenic, radon-222, residue on evaporation, total and fecal coliform including Escherichia coli and heterotrophic plate count.
\end{abstract}

\section{Introduction}

Section 305(b) of the Federal Clean Water Act Amendments of 1977 requires that states monitor and report biennially on the chemical quality of surface water and groundwater within state boundaries (U.S. Environmental Protection Agency, 1997). The U.S. Geological Survey (USGS) in 2002, in cooperation with the New York State Department of Environmental Conservation (NYSDEC), developed a program to evaluate groundwater quality throughout the major river basins in New York on a rotating basis. The program parallels the NYSDEC Rotating Intensive Basin Study program, which evaluates surface-water quality in 2 or 3 of the 14 major river basins in the State each year. The groundwater-quality program began in 2002 with a pilot study in the Mohawk River Basin and has continued throughout upstate New York since then (table 1). Sampling completed in 2008 represented the conclusion of a first round of groundwater-quality sampling throughout New York State (excluding Long Island, which is monitored through local County programs). Groundwater-quality sampling was conducted in 2009 in the Lake Champlain and Upper Susquehanna River Basins; these basins also were sampled in 2004 as part of this study. This report presents the results of the 2009 groundwater study in the Upper Susquehanna River Basin in south-central New York.

Groundwater characteristics are affected by the geology and the land use of the area. Shallow wells that tap into sand and gravel aquifers are susceptible to contamination by several kinds of compounds, including volatile organic compounds (VOCs), pesticides, deicing chemicals, and nutrients from upgradient highways, industrial, agricultural, and residential areas. The movement of these contaminants to the water table through the soils and surficial sand and gravel can be relatively rapid. Bedrock wells that tap into sandstone and shale aquifers in rural upland areas generally are less susceptible to contamination from industrial and urban sources, which are mainly in the valleys; but bedrock wells in lowland areas underlain by carbonate rock (limestone and dolostone) may be more vulnerable to contamination from surface runoff because infiltration rates and groundwater flow can be relatively rapid through solution features in the rock. Agricultural land upgradient of wells may be a potential source of contamination from fertilizers, pesticides, and fecal waste from livestock; lawns and residential septic systems also are a potential source of these contaminants. In addition to anthropogenic contaminants, the aquifers contain naturally derived constituents that may diminish water quality, such as sodium, chloride, sulfate, iron, manganese, arsenic, hydrogen sulfide, methane, and radon gases. 
Table 1. Previous groundwater-quality studies and reports.

\begin{tabular}{llll}
\hline \multicolumn{1}{c}{ Study Area } & Year & \multicolumn{1}{c}{ Report } & \multicolumn{1}{c}{ Reference } \\
\hline Mohawk River Basin & 2002 & Water-Data Report NY-02-1 & Butch and others, 2003 \\
Chemung River Basin & 2003 & Open-File Report 2004-1329 & Hetcher-Aguila, 2005 \\
Lake Champlain Basin & 2004 & Open-File Report 2006-1088 & Nystrom, 2006 \\
Upper Susquehanna River Basin & 2004 & Open-File Report 2006-1161 & Hetcher-Aguila and Eckhardt, 2006 \\
Delaware River Basin & 2005 & Open-File Report 2007-1098 & Nystrom, 2007b \\
Genesee River Basin & 2005 & Open-File Report 2007-1093 & Eckhardt and others, 2007 \\
St. Lawrence River Basin & 2005 & Open-File Report 2007-1066 & Nystrom, 2007a \\
Mohawk River Basin & 2006 & Open-File Report 2008-1086 & Nystrom, 2008 \\
Western New York & 2006 & Open-File Report 2008-1140 & Eckhardt and others, 2008 \\
Central New York & 2007 & Open-File Report 2009-1257 & Eckhardt and others, 2009 \\
Upper Hudson River Basin & 2007 & Open-File Report 2009-1240 & Nystrom, 2009 \\
Eastern Lake Ontario Basin & 2008 & Open-File Report 2011-1074 & Risen and Reddy, 2011a \\
Chemung River Basin & 2008 & Open-File Report 2011-1112 & Risen and Reddy, 2011b \\
Lower Hudson River Basin & 2008 & Open-File Report 2010-1197 & Nystrom, 2010 \\
\hline
\end{tabular}

\section{Purpose and Scope}

This report supplements the water-quality study completed in 2004 in the Upper Susquehanna River Basin (Hetcher-Aguila and Eckhardt, 2006) by re-sampling 6 of the wells from that study (wells BM 90, BM 375, M 595, OG 6, OG 504, and OG 846) and provides analytical results for 24 new wells (fig. 1). This report briefly describes the study area and the sampling methods, and presents results of the 2009 water-quality analyses. Summary statistics (number of samples exceeding Federal or State drinking-water standards) and the minimum, median, and maximum concentrations of selected analytes for 30 samples from wells in sand and gravel and bedrock aquifers are provided in tables 1-3; information on the sampled wells and detailed analytical results for all analytes are provided in tables 1-1 through 1-13 (appendix at end of report).

\section{Study Area}

The Upper Susquehanna River Basin lies mostly in south-central New York and partly in north-central Pennsylvania (fig. 1). A complete description of the study area is included in the first Upper Susquehanna River Basin report (Hetcher-Aguila and Eckhardt, 2006). Briefly, the study area (4,522-square miles $\left.\left(\mathrm{mi}^{2}\right)\right)$ includes all or parts of 15 counties in south-central New York. The study area lies within the Appalachian Plateau physiographic province and includes the Upper Susquehanna subbasin, the Chenango River subbasin, and the Owego Creek-Wappasening Creek subbasin (fig. 1). The study area is predominantly rural, although it contains several small cities (Oneonta, Binghamton, Norwich, and Cortland, fig.1) and many villages. Most of the developed areas are within the Susquehanna, Unadilla, Chenango, and Tioughnioga River valleys (fig. 1). The main valley of the Susquehanna River trends northeast-southwest and is about 1 mile (mi) wide in most places. The Susquehanna River Basin drains most of south-central New York and one-half of Pennsylvania and eventually flows into Chesapeake Bay (fig. 1).

During deglaciation of the region, sand and gravel were deposited by meltwater streams and clay, silt, and fine sand were deposited in proglacial lakes. The glaciofluvial and glaciolacustrine deposits within the study area are described in detail by Randall (2001), Fleisher (1977a,b; 1986), MacNish and Randall (1982), and (Coates, 1966). The most productive aquifers within the study area are the glaciofluvial deposits of sand and gravel in the valleys. Bedrock aquifers typically are used for water supply in upland areas where sand and gravel aquifers are absent. The bedrock aquifers throughout most of the study area consist of fractured shale and sandstone; carbonate-bedrock aquifers of fractured and solutioned limestone and dolostone are limited to a small area in the northern part of the basin.

\section{Methods}

A total of 30 wells (table 1-1) were selected for sample collection as described by Hetcher-Aguila and Eckhardt (2006) - 16 were finished in sand and gravel aquifers, and 14 were finished in bedrock aquifers. Of the 16 wells that tap into sand and gravel aquifers, 14 are production wells and 2 are private residential wells. Of the 14 bedrock wells, 2 are production wells and 12 are 

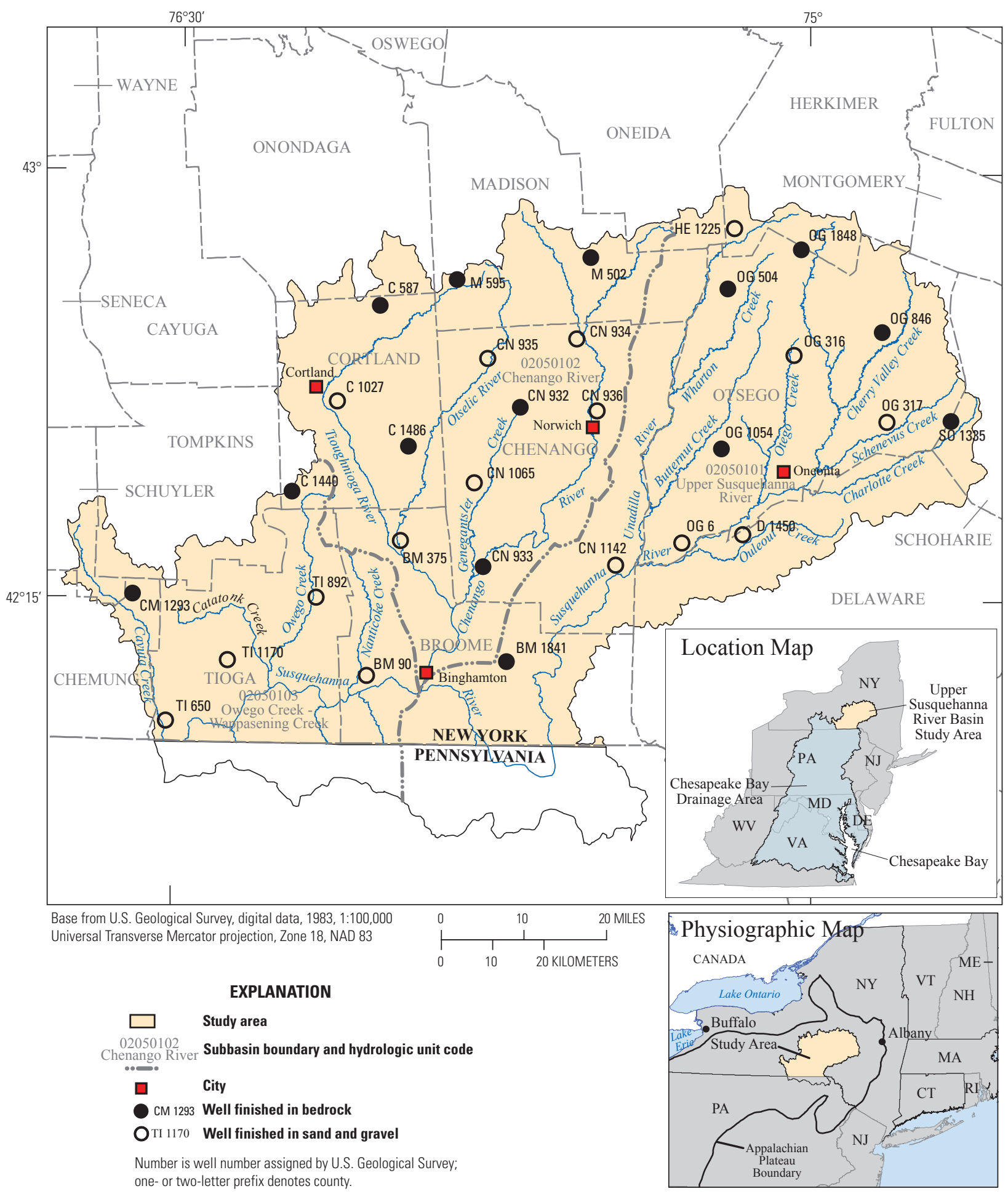

Figure 1. Pertinent geographic features of study area in the Upper Susquehanna River Basin, New York, and locations of the 30 wells sampled in 2009. (Well data are provided in table 1-1, at end of report.) 
private residential wells. Samples were collected from August through December 2009. The water samples were analyzed for 10 physical properties and 137 constituents, including 4 types of bacterial analyses. Two samples (one field blank and one replicate sample) were collected for quality assurance (QA) and quality control (QC), as required for the Federal 305(b) program.

Samples were collected from every well for these analyses and were processed by methods described in U.S. Geological Survey (USGS) manuals for the collection of water-quality data (U.S. Geological Survey, variously dated). A detailed description of the sampling and analytical methods is provided by Hetcher-Aguila and Eckhardt (2006). Samples collected for pesticide analyses were processed by the methods of Shelton (1994), Sandstrom and others (2001), and Wilde and others (2004). These samples were analyzed through gas chromatography-mass spectrometry (GC-MS) and high-performance liquid chromatography-mass spectrometry (HPLC-MS), as described by Zaugg and others (1995), Furlong and others (2001), Sandstrom and others (2001), Meyer and others (1993), and Lee and Strahan (2003). The analytical method devised by Zaugg and others (1995) was developed in cooperation with the U.S. Environmental Protection Agency (USEPA) and allows detection of the Nation's most commonly used pesticides. VOCs were analyzed by GC-MS using methods described by Connor and others (1998).

Radon-222 activities were measured through liquid-scintillation counting (ASTM International, 2009). Gross alpha and gross beta radioactivities were measured through gas flow proportional counting according to USEPA method 900.0 (U.S. Environmental Protection Agency, 1980). Carbon dioxide and methane concentrations were measured through gas chromatography with flame ionization detection; dissolved nitrogen gas and argon concentration were measured through gas chromatography with thermal conductivity detection. Total organic carbon samples were analyzed by high temperature combustion and catalytic oxidation for measurement by infrared detection (American Public Health Association, 2005, Standard Method 5310 B). Mercury concentrations were measured through cold vapor-atomic fluorescence spectrometry according to methods described by Garbarino and Damrau (2001). Arsenic, chromium, and nickel analyses used collision/reaction cell inductively coupled plasmamass spectrometry (cICP-MS) as described by Garbarino and others (2006). The remaining trace elements were analyzed by inductively coupled plasma-atomic emission spectrometry (ICP-AES) (Struzeski and others, 1996), inductively coupled plasmaoptical emission spectrometry (ICP-OES), and inductively coupled plasma-mass spectrometry (ICP-MS) (Garbarino and Struzeski, 1998). In-bottle digestions for trace-element analyses described by Hoffman and others (1996) were followed. Samples for bacterial analyses were processed in accordance with New York State Department of Health (NYSDOH) guidelines.

The analyses for physical properties, most trace elements and metals, acid-neutralizing capacity, organic carbon, radiochemicals, and VOCs were done on unfiltered water samples to obtain total whole-water concentrations. Dissolved concentrations of nutrients, major inorganic constituents, three metals, and pesticides were obtained from filtered samples. Concentrations of iron and manganese were measured in filtered and unfiltered samples to provide the total and dissolved concentrations (table 1-6). Hydrochloric acid was added to samples collected for VOC, and mercury analyses, and nitric acid was added to samples collected for gross alpha and gross beta analyses and some of the samples collected for trace-element analyses to prevent sample degradation. Samples collected for dissolved inorganic-compound analyses were filtered through a 0.45 -micrometer $(\mu \mathrm{m})$ polyether sulfone capsule filter; samples for pesticide analysis were filtered through a $0.7-\mu \mathrm{m}$ furnace-baked glass-fiber plate filter by the methods of Wilde and others (2004).

All samples except those for radiochemical analyses were chilled to 4 degrees Celsius $\left({ }^{\circ} \mathrm{C}\right)$ or less and were kept chilled until delivery to the analyzing laboratory. The samples were delivered directly, or shipped by overnight delivery, to four laboratories: (1) the USGS National Water Quality Laboratory (NWQL) in Denver, Colorado, for analysis for inorganic major ions, nutrients, total organic carbon, inorganic trace elements and radon-222, pesticides and pesticide degradates, and VOCs; (2) the USGS Chlorofluorocarbon Laboratory (CFCL) in Reston, Virginia., for select dissolved gases; (3) a NYSDOH-certified laboratory in Richmond, California, for gross alpha and gross beta radioactivities; and (4) a NYSDOH-certified laboratory in Ithaca, New York for bacterial analysis.

\section{Groundwater Quality}

Samples from 30 wells were analyzed for 147 constituents and physical properties. Many of these (74) were not detected above the laboratory reporting levels (LRLs) in any sample (table 1-2). Results for the remaining 73 constituents and properties that were detected are presented in tables 1-3 through 1-13 (at end of report). The categories are as follows: physical properties (table 1-3), inorganic constituents (table 1-4), nutrients and total organic carbon (table 1-5), trace elements and radiochemicals (table 1-6), pesticides (table 1-7), VOCs (table 1-8), and bacterial water-quality indicators (table 1-9). Some concentrations were reported as "estimated" when the detected value was less than the established LRL, or when recovery of a compound has been documented to be highly variable (Childress and others, 1999).

Analytical results for selected constituents were compared with Federal and New York State drinking-water standards, which are typically identical. The standards include Maximum Contaminant Levels (MCLs), Secondary Maximum Contaminant Levels (SMCLs), and Health Advisories (HAs) established by the USEPA (U.S. Environmental Protection Agency, 1999; 2002; 
and 2009) and the NYSDOH (New York State Department of Health, 2007). MCLs are enforceable standards that specify the highest level of a contaminant that is allowed in public water drinking supplies; they are not enforceable for private homeowner wells, but are presented here as a guideline for evaluation of the water results. SMCLs are nonenforceable guidelines based on cosmetic and aesthetic criteria, such as taste and odor. HAs are estimates of acceptable drinking-water levels for contaminants that can affect human health; they are nonenforceable guidelines that provide technical guidance for water use.

The QA/QC field blank contained no constituent in concentrations greater than the LRLs, except mercury, which was detected at a trace concentration of 0.39 micrograms per liter $(\mu \mathrm{g} / \mathrm{L})$; however, mercury was not detected in any of the environmental samples at a concentration greater than the LRL. This indicates that little to no contamination occurred through the sampling or analytical procedures. The results of analysis of the QA/QC replicate sample indicates that variability in sample results meet the precision requirements of the study. The analytes with the largest percent differences between concentration in a groundwater sample and that in the replicate sample were acid-neutralizing capacity, residue on evaporation, and low-concentration trace elements (concentrations near the LRL for the elements).

The quality of the sampled groundwater genrally was acceptable, although in samples from 28 of the 30 wells the concentrations of at least 1 constituent exceeded recommended MCLs, SMCLs, or HAs set by the USEPA and the NYSDOH. Exceedances generally involved minerals that occur from natural interactions of water and rock (arsenic, iron, manganese, sodium), but also included bacterial contamination. A total of 17 of the wells tested exceeded the USEPA proposed MCL for radon-222, which is generated from the natural decay of uranium.

\section{Physical Properties and Dissolved Gases}

The $\mathrm{pH}$ of the samples (table 1-3) ranged from 6.3 to 9.2 ; the median was $\mathrm{pH} 7.5$ for sand and gravel wells and $\mathrm{pH} 7.9$ for bedrock wells. There were four bedrock wells that had $\mathrm{pH}$ values outside the accepted USEPA SMCL range of $\mathrm{pH} 6.5$ to 8.5 (U.S. Environmental Protection Agency, 2009). The temperature of the water ranged from $8.7^{\circ} \mathrm{C}$ to $17.5^{\circ} \mathrm{C}$; the median was $11.0^{\circ} \mathrm{C}$ for sand and gravel wells and $12.8^{\circ} \mathrm{C}$ for bedrock wells. Specific conductance of the samples ranged from 105 to 1,220 microsiemens per centimeter $(\mu \mathrm{S} / \mathrm{cm})$ at $25^{\circ} \mathrm{C}$; the median was $390 \mu \mathrm{S} / \mathrm{cm}$ at $25^{\circ} \mathrm{C}$ for sand and gravel wells and $378 \mu \mathrm{S} / \mathrm{cm}$ at $25^{\circ} \mathrm{C}$ for bedrock wells. The color of the water samples ranged from less than 1 platinum-cobalt (Pt-Co) unit (the LRL) to 5 Pt-Co units; the median was less than 1 Pt-Co units for sand and gravel wells and 2 Pt-Co units for bedrock wells.

Dissolved-oxygen concentrations ranged from less than 0.1 milligram per liter $(\mathrm{mg} / \mathrm{L}$ ) (the LRL) to $8.2 \mathrm{mg} / \mathrm{L}$; the median was $3.2 \mathrm{mg} / \mathrm{L}$ for sand and gravel wells and $0.4 \mathrm{mg} / \mathrm{L}$ for bedrock wells. Dissolved-nitrogen concentrations ranged from 18.7 $\mathrm{mg} / \mathrm{L}$ to $30.6 \mathrm{mg} / \mathrm{L}$; the median was $20.8 \mathrm{mg} / \mathrm{L}$ for sand and gravel wells and $24.6 \mathrm{mg} / \mathrm{L}$ for bedrock wells. Carbon dioxide concentrations ranged from $0.2 \mathrm{mg} / \mathrm{L}$ to $42 \mathrm{mg} / \mathrm{L}$; the median was $17.5 \mathrm{mg} / \mathrm{L}$ for sand and gravel wells and $5.6 \mathrm{mg} / \mathrm{L}$ for bedrock wells. Methane concentrations ranged from less than $0.0005 \mathrm{mg} / \mathrm{L}$ (the LRL) to $22.4 \mathrm{mg} / \mathrm{L}$; the median was less than 0.0005 $\mathrm{mg} / \mathrm{L}$ for sand and gravel wells and $0.15 \mathrm{mg} / \mathrm{L}$ for bedrock wells. Argon concentrations ranged from $0.652 \mathrm{mg} / \mathrm{L}$ to $0.935 \mathrm{mg} / \mathrm{L}$; the median was $0.735 \mathrm{mg} / \mathrm{L}$ for sand and gravel wells and $0.830 \mathrm{mg} / \mathrm{L}$ for bedrock wells. The odor of hydrogen sulfide gas, which may occur in the absence of oxygen, was noted by field personnel in water from eight bedrock wells.

\section{Major lons}

The cations that were detected in the greatest concentrations were calcium and sodium (tables 1 and 1-4). Calcium concentrations ranged from 2.21 to $128 \mathrm{mg} / \mathrm{L}$; the median was $45.7 \mathrm{mg} / \mathrm{L}$ for sand and gravel wells and $28.2 \mathrm{mg} / \mathrm{L}$ for bedrock wells. Magnesium concentrations ranged from 0.424 to $20.3 \mathrm{mg} / \mathrm{L}$; the median was $7.37 \mathrm{mg} / \mathrm{L}$ for sand and gravel wells and $4.82 \mathrm{mg} / \mathrm{L}$ for bedrock wells. Potassium concentrations ranged from 0.23 to $3.75 \mathrm{mg} / \mathrm{L}$; the median was $1.24 \mathrm{mg} / \mathrm{L}$ for sand and gravel wells and $0.50 \mathrm{mg} / \mathrm{L}$ for bedrock wells. Sodium concentrations ranged from 1.96 to $170 \mathrm{mg} / \mathrm{L}$; the median was $20.3 \mathrm{mg} / \mathrm{L}$ for sand and gravel wells and $36.8 \mathrm{mg} / \mathrm{L}$ for bedrock wells. Results indicate six samples exceeded the USEPA nonregulatory drinking-water advisory taste threshold, which recommends that sodium concentrations in drinking water not exceed the range of 30 to $60 \mathrm{mg} / \mathrm{L}$ (U.S. Environmental Protection Agency, 2002; 2009).

The anion that was detected in the greatest concentration was bicarbonate, which is a measure of alkalinity and contributes to residue on evaporation (tables 1 and 1-4). Bicarbonate concentrations ranged from 45 to $329 \mathrm{mg} / \mathrm{L}$; the median was $181 \mathrm{mg} / \mathrm{L}$ for sand and gravel wells and $206 \mathrm{mg} / \mathrm{L}$ for bedrock wells. Chloride concentrations ranged from 0.71 to $201 \mathrm{mg} / \mathrm{L}$; the median was $34.0 \mathrm{mg} / \mathrm{L}$ for sand and gravel wells and $5.79 \mathrm{mg} / \mathrm{L}$ for bedrock wells. Fluoride concentrations ranged from an estimate of $0.04 \mathrm{mg} / \mathrm{L}$ to $0.74 \mathrm{mg} / \mathrm{L}$; the median was an estimate of $0.06 \mathrm{mg} / \mathrm{L}$ for sand and gravel wells and $0.23 \mathrm{mg} / \mathrm{L}$ for bedrock wells. Silica concentrations ranged from $4.76 \mathrm{mg} / \mathrm{L}$ to $14.3 \mathrm{mg} / \mathrm{L}$; the median was $7.13 \mathrm{mg} / \mathrm{L}$ for sand and gravel wells and $8.29 \mathrm{mg} / \mathrm{L}$ for bedrock wells. Sulfate concentrations ranged from an estimate of 0.17 to $36.0 \mathrm{mg} / \mathrm{L}$; the median was $14.5 \mathrm{mg} / \mathrm{L}$ for sand and gravel wells and $7.51 \mathrm{mg} / \mathrm{L}$ for bedrock wells. 
Table 2. Summary statistics for concentrations of major ions in sand and gravel aquifers and bedrock aquifers in the Upper Susquehanna River Basin, New York, 2009.

[Concentrations are in milligrams per liter. All samples represent filtered water; --, not applicable; <, less than; E, estimated value-constituent was detected in the sample but with low or inconsistent recovery; $\mathrm{CaCO} 3$, calcium carbonate]

\begin{tabular}{|c|c|c|c|c|c|c|c|c|c|}
\hline \multicolumn{2}{|c|}{ Constituent } & \multirow[t]{2}{*}{$\begin{array}{c}\text { Drinking- } \\
\text { water standard }\end{array}$} & \multirow{2}{*}{$\begin{array}{c}\text { Number of } \\
\text { samples } \\
\text { exceeding } \\
\text { standard }\end{array}$} & \multicolumn{3}{|c|}{$\begin{array}{l}\text { Sand and gravel } \\
\text { (16 samples) }\end{array}$} & \multicolumn{3}{|c|}{$\begin{array}{c}\text { Bedrock } \\
\text { (14 samples) }\end{array}$} \\
\hline & & & & Minimum & Median & Maximum & Minimum & Median & Maximum \\
\hline \multirow{4}{*}{ 苞 } & Calcium & -- & -- & 21.8 & 45.7 & 128 & 2.21 & 28.2 & 81.9 \\
\hline & Magnesium & -- & -- & 2.62 & 7.37 & 20.3 & .424 & 4.82 & 10.3 \\
\hline & Potassium & -- & -- & .58 & 1.24 & 3.75 & .23 & .50 & 1.50 \\
\hline & Sodium & $60^{\mathrm{a}}$ & 6 & 1.96 & 20.3 & 99.7 & 2.96 & 36.8 & 170 \\
\hline \multirow{4}{*}{$\stackrel{0}{0}$} & Bicarbonate & -- & -- & 46 & 181 & 329 & 45 & 206 & 287 \\
\hline & Chloride & $250^{b}$ & 0 & 1.97 & 34.0 & 201 & .71 & 5.79 & 176 \\
\hline & Fluoride & $2.0^{\mathrm{c}}, 2.2^{\mathrm{b}}$ & 0 & $<.08$ & E.06 & .21 & Е .04 & .23 & .74 \\
\hline & Sulfate & $250^{\mathrm{b}, \mathrm{c}}$ & 0 & 3.44 & 14.5 & 36.0 & E.17 & 7.51 & 33.9 \\
\hline \multicolumn{2}{|c|}{ Hardness as $\mathrm{CaCO}_{3}$} & -- & -- & 65 & 145 & 400 & 7 & 96 & 230 \\
\hline \multicolumn{2}{|c|}{ Alkalinity as $\mathrm{CaCO}_{3}$} & -- & -- & 38 & 148 & 270 & 37 & 168 & 235 \\
\hline \multicolumn{2}{|c|}{ Residue on evaporation } & $500^{c}$ & 3 & 83 & 207 & 736 & 60 & 206 & 506 \\
\hline
\end{tabular}

${ }^{a}$ U.S. Environmental Protection Agency Drinking Water Advisory Taste Threshold.

${ }^{\mathrm{b}}$ New York State Department of Health Maximum Contaminant Level.

${ }^{c}$ U.S. Environmental Protection Agency Secondary Maximum Contaminant Level.

Calcium and magnesium contribute to water hardness. Water hardness in the basin ranged from 7 to $400 \mathrm{mg} / \mathrm{L}$ (as $\mathrm{CaCO}_{3}$ ); the median was $145 \mathrm{mg} / \mathrm{L}$ for sand and gravel wells and $96 \mathrm{mg} / \mathrm{L}$ for bedrock wells. Sixteen of the samples were soft to moderately hard $\left(120 \mathrm{mg} / \mathrm{L}\right.$ as $\mathrm{CaCO}_{3}$ or less); and 14 wells yielded water that was hard to very hard (greater than $120 \mathrm{mg} / \mathrm{L}$ as $\mathrm{CaCO}_{3}$ ) (Hem, 1985). Wells finished in bedrock were slightly more alkaline (median $168 \mathrm{mg} / \mathrm{L}$ as $\mathrm{CaCO}_{3}$ ) than those finished in sand and gravel (median $148 \mathrm{mg} / \mathrm{L}$ as $\mathrm{CaCO}_{3}$ ). Residue on evaporation is a measure of total dissolved solids, and ranged from 60 to $736 \mathrm{mg} / \mathrm{L}$. The median residue on evaporation was $207 \mathrm{mg} / \mathrm{L}$ for sand and gravel wells and $206 \mathrm{mg} / \mathrm{L}$ for bedrock wells; three samples exceeded the USEPA SMCL of $500 \mathrm{mg} / \mathrm{L}$.

\section{Nutrients and Organic Carbon}

Nitrate was the predominant nutrient in the groundwater samples (tables 2 and 1-5). Nitrate plus nitrite concentrations ranged from less than 0.04 (the LRL) to $3.72 \mathrm{mg} / \mathrm{L}$ as nitrogen $(\mathrm{N})$; the median concentration was $1.18 \mathrm{mg} / \mathrm{L}$ in samples from sand and gravel wells and less than $0.04 \mathrm{mg} / \mathrm{L}$ in samples from bedrock wells. However, nitrite concentrations were typically low; the maximum concentration was $0.040 \mathrm{mg} / \mathrm{L}$. No samples exceeded the nitrate or nitrite MCLs. Ammonia concentrations ranged from less than 0.020 (the $\mathrm{LRL}$ ) to $0.303 \mathrm{mg} / \mathrm{L}$ as $\mathrm{N}$. Orthophosphate concentrations ranged from an estimate of 0.005 to $0.311 \mathrm{mg} / \mathrm{L}$ as phosphorus $(\mathrm{P})$. Total organic carbon concentrations ranged from an estimate of $0.4 \mathrm{mg} / \mathrm{L}$ to $2.5 \mathrm{mg} / \mathrm{L}$.

\section{Trace Elements and Radiochemicals}

The trace elements detected in the greatest concentrations $(>100 \mu \mathrm{g} / \mathrm{L})$ were barium, boron, copper, iron, lithium, manganese, strontium, and zinc (tables 3 and 1-6). Boron, lithium, and strontium were detected at greater concentrations in bedrock wells compared to sand and gravel wells. Barium concentrations ranged from $5.7 \mu \mathrm{g} / \mathrm{L}$ to $944 \mu \mathrm{g} / \mathrm{L}$. Boron concentrations 
Table 3. Summary statistics for concentrations of nutrients and organic carbon in sand and gravel aquifers and bedrock aquifers in the Upper Susquehanna River Basin, New York, 2009.

[All samples represent filtered water except as noted; N, nitrogen; $\mathrm{mg} / \mathrm{L}$, milligrams per liter; --, not applicable; <, less than; E, estimated value- constituent was detected in the sample but with low or inconsistent recovery; P, phosphorus]

\begin{tabular}{|c|c|c|c|c|c|c|c|c|}
\hline \multirow[t]{2}{*}{ Constituent } & \multirow{2}{*}{$\begin{array}{c}\text { Drink- } \\
\text { ing- } \\
\text { water } \\
\text { stan- } \\
\text { dard }\end{array}$} & \multirow{2}{*}{$\begin{array}{l}\text { Num- } \\
\text { ber of } \\
\text { samples } \\
\text { exceed- } \\
\text { ing limit }\end{array}$} & \multicolumn{3}{|c|}{$\begin{array}{l}\text { Sand and gravel } \\
\text { (16 samples) }\end{array}$} & \multicolumn{3}{|c|}{$\begin{array}{c}\text { Bedrock } \\
\text { (14 samples) }\end{array}$} \\
\hline & & & Minimum & Median & Maximum & Minimum & Median & Maximum \\
\hline Ammonia plus organic $\mathrm{N}, \mathrm{mg} / \mathrm{L}$ as $\mathrm{N}$ & -- & -- & $<0.10$ & Е 0.08 & 0.33 & $<0.10$ & 0.18 & 0.37 \\
\hline Ammonia, $\mathrm{mg} / \mathrm{L}$ as $\mathrm{N}$ & -- & -- & $<.020$ & $<.020$ & .269 & $<.020$ & .092 & .303 \\
\hline Nitrate plus nitrite, $\mathrm{mg} / \mathrm{L}$ as $\mathrm{N}$ & $10^{\mathrm{a}, \mathrm{b}}$ & 0 & $<.04$ & 1.18 & 3.72 & $<.04$ & $<.04$ & .89 \\
\hline Nitrite, $\mathrm{mg} / \mathrm{L}$ as $\mathrm{N}$ & $1^{\mathrm{a}, \mathrm{b}}$ & 0 & $<.002$ & $<.002$ & $<.002$ & $<.002$ & $<.002$ & .040 \\
\hline Orthophosphate, $\mathrm{mg} / \mathrm{L}$ as $\mathrm{P}$ & -- & -- & E.005 & E.008 & .311 & $<.008$ & .012 & .046 \\
\hline Total organic carbon, unfiltered, mg/L & -- & -- & $<.6$ & E.4 & 1.7 & $<.6$ & E.6 & 2.5 \\
\hline
\end{tabular}

${ }^{a}$ U.S. Environmental Protection Agency Drinking Water Advisory Taste Threshold.

${ }^{\mathrm{b}}$ New York State Department of Health Maximum Contaminant Level.

ranged from 4.1 to $732 \mu \mathrm{g} / \mathrm{L}$. Copper concentrations ranged from an estimate of $1.0 \mu \mathrm{g} / \mathrm{L}$ to $267 \mu \mathrm{g} / \mathrm{L}$. Iron concentrations in filtered samples ranged from an estimate of $2 \mu \mathrm{g} / \mathrm{L}$ to $1,400 \mu \mathrm{g} / \mathrm{L}$; the Federal SMCL and the New York State MCL for iron (300 $\mu \mathrm{g} / \mathrm{L})$ was exceeded in filtered samples from one sand and gravel well and one bedrock well. Lithium concentrations ranged from $0.7 \mu \mathrm{g} / \mathrm{L}$ to $347 \mu \mathrm{g} / \mathrm{L}$. Manganese concentrations in filtered samples ranged from less than $0.2 \mu \mathrm{g} / \mathrm{L}$ (the LRL) to $937 \mu \mathrm{g} / \mathrm{L}$; the Federal SMCL for manganese $(50 \mu \mathrm{g} / \mathrm{L})$ was exceeded in filtered samples from four sand and gravel wells and four bedrock wells. The NYSDOH MCL for manganese $(300 \mu \mathrm{g} / \mathrm{L})$ was exceeded in one filtered sample from a sand and gravel well. Strontium concentrations ranged from $22.8 \mu \mathrm{g} / \mathrm{L}$ to $1,110 \mu \mathrm{g} / \mathrm{L}$. Zinc concentrations ranged from an estimate of 1.3 to $178 \mu \mathrm{g} / \mathrm{L}$.

Other trace elements were detected at low to moderate concentrations (as much as $100 \mu \mathrm{g} / \mathrm{L}$ ). Aluminum concentrations ranged from less than 6 (the LRL) to $59 \mu \mathrm{g} / \mathrm{L}$; the Federal SMCL $(50 \mu \mathrm{g} / \mathrm{L}$ ) was exceeded in two bedrock well samples. Arsenic concentrations ranged from an estimate of 0.11 to $18.4 \mathrm{mg} / \mathrm{L}$; the Federal and NYSDOH MCL $(10 \mu \mathrm{g} / \mathrm{L})$ was exceeded in one sand and gravel well sample. Lead concentrations ranged from an estimate of 0.06 to $6.97 \mu \mathrm{g} / \mathrm{L}$. Nickel concentrations ranged from less than 0.20 (the LRL) to $1.8 \mu \mathrm{g} / \mathrm{L}$. Uranium concentrations ranged from an estimate of 0.014 to $1.12 \mu \mathrm{g} / \mathrm{L}$. Some trace elements were detected less frequently or at lower concentrations (no more than $1 \mu \mathrm{g} / \mathrm{L}$ ); these include antimony, cadmium, chromium, cobalt, mercury, selenium, and silver. Beryllium and thallium were not detected in any sample (table 1-2).

Three measures of radioactivity were employed (tables 3 and 1-6). Gross alpha activity ranged from less than 0.58 to 4.9 pico curies per liter (pCi/L). Gross beta activity ranged from 0.7 to $5.0 \mathrm{pCi} / \mathrm{L}$. Radon- 222 was detected in every sample, and activity ranged from 22 to $1,140 \mathrm{pCi} / \mathrm{L}$. The median activity was $600 \mathrm{pCi} / \mathrm{L}$ in samples from sand and gravel wells and 222 $\mathrm{pCi} / \mathrm{L}$ in samples from bedrock wells. Radon currently is not regulated in drinking water; however, the USEPA proposed MCL of $300 \mathrm{pCi} / \mathrm{L}$ for radon-222 in drinking water was exceeded in 17 samples, but the USEPA proposed Alternate Maximum Contaminant Level (AMCL) of 4,000 pCi/L was not exceeded. The AMCL is the proposed allowable activity of radon in raw-water samples where the State has implemented mitigation programs to address the health risks of radon in indoor air. The proposed MCL and AMCL for radon are under review and have not been adopted (U.S. Environmental Protection Agency, 1999, 2009).

\section{Pesticides}

Five herbicides and 1 degradate were detected in samples from 12 sand and gravel wells and 1 bedrock well (table 1-7). The term degradate refers to a pesticide breakdown product resulting from biological or chemical processes. Atrazine or the triazine degradate CIAT (2-chloro-4-isopropylamino-6-amino-s-triazine, also called deethylatrazine) were detected in samples from 12 of the 16 sand and gravel wells. Estimated measurements were made for most of the atrazine and CIAT detections, 
Table 4. Summary statistics for concentrations of trace elements and radiochemicals in sand and gravel aquifers and bedrock aquifers in the Upper Susquehanna River Basin, New York, 2009.

[All concentrations are in micrograms per liter except as noted. All samples unfiltered except as noted; <, less than ; E, estimated value —constituent was detected in the sample but with low or inconsistent recovery; --, not applicable; $\mathrm{pCi} / \mathrm{L}$, picocuries per liter; mrem/yr, millirem per year]

\begin{tabular}{|c|c|c|c|c|c|c|c|c|}
\hline \multirow[t]{2}{*}{ Constituent } & \multirow[t]{2}{*}{$\begin{array}{l}\text { Drinking- } \\
\text { water } \\
\text { standard }\end{array}$} & \multirow{2}{*}{$\begin{array}{l}\text { Number of } \\
\text { samples } \\
\text { exceeding } \\
\text { standard }\end{array}$} & \multicolumn{3}{|c|}{$\begin{array}{c}\text { Sand and gravel } \\
\text { (16 samples) }\end{array}$} & \multicolumn{3}{|c|}{$\begin{array}{c}\text { Bedrock } \\
\text { (14 samples) }\end{array}$} \\
\hline & & & Minimum & Median & Maximum & Minimum & Median & Maximum \\
\hline Aluminum & $50^{c}$ & 2 & $<6$ & $<6$ & 24 & $<6$ & E 4 & 59 \\
\hline Antimony & $6^{a, b}$ & 0 & $<.4$ & $<.4$ & E. 2 & $<.4$ & $<.4$ & $<.4$ \\
\hline Arsenic & $10^{a, b}$ & 1 & .25 & $<.64$ & 18.4 & E.11 & .56 & 5.1 \\
\hline Barium & $2,000^{\mathrm{a}, \mathrm{b}}$ & 0 & 5.7 & 65.0 & 640 & 14.6 & 86.6 & 944 \\
\hline Boron, filtered & -- & -- & 7.6 & 21 & 87 & 4.1 & 236 & 732 \\
\hline Cadmium & $5^{\mathrm{a}, \mathrm{b}}$ & 0 & $<.04$ & $<.04$ & .07 & $<.04$ & $<.06$ & .04 \\
\hline Chromium & $100^{a, b}$ & 0 & $<.40$ & $<.42$ & E. 33 & $<.40$ & $<.4$ & E. 31 \\
\hline Cobalt & -- & -- & $<.04$ & Е.04 & .13 & $<.04$ & $<.10$ & .11 \\
\hline Copper & $1,000^{c}$ & 0 & E.10 & 2.8 & 51.5 & 2.9 & 5.2 & 267 \\
\hline Iron, filtered & $300^{\mathrm{b}, \mathrm{c}}$ & 2 & E 2 & 6 & 1,400 & E 3 & 20 & 346 \\
\hline Iron & $300^{b, c}$ & 5 & $<9$ & 14 & 1,420 & E 10 & 68 & 990 \\
\hline Lead & $15^{\mathrm{d}}$ & 0 & E. 06 & .24 & 6.97 & $<.10$ & .30 & 1.94 \\
\hline Lithium & -- & -- & .7 & 2.9 & 13.4 & 1.6 & 31.4 & 347 \\
\hline Manganese, filtered & $50^{\mathrm{c}}, 300^{\mathrm{b}}$ & 8,1 & $<.2$ & .5 & 937 & E. 2 & 32.1 & 183 \\
\hline Manganese & $50^{\mathrm{c}}, 300^{\mathrm{b}}$ & 10,1 & $<.8$ & .8 & 1,060 & E. 4 & 33.2 & 184 \\
\hline Mercury & $2^{a, b}$ & 0 & $<.010$ & $<.010$ & $<.010$ & $<.010$ & $<.010$ & E. 010 \\
\hline Molybdenum & -- & -- & $<.1$ & E.1 & .7 & $<.1$ & .2 & 5.0 \\
\hline Nickel & -- & -- & $<.20$ & Е. 34 & 1.8 & $<.20$ & E.14 & 1.3 \\
\hline Selenium & $50^{\mathrm{a}, \mathrm{b}}$ & 0 & $<.10$ & Е. 07 & .30 & $<.10$ & $<.12$ & Е .07 \\
\hline Silver & $100^{\mathrm{a}, \mathrm{b}}$ & 0 & $<.02$ & $<.02$ & E. 01 & $<.02$ & $<.06$ & $<.06$ \\
\hline Strontium & -- & -- & 43.0 & 128 & 444 & 22.8 & 358 & 1,110 \\
\hline Uranium & $30^{\mathrm{a}, \mathrm{b}}$ & 0 & E.020 & .183 & 1.12 & E.014 & .034 & .574 \\
\hline Zinc & $5,000^{\mathrm{b}, \mathrm{c}}$ & 0 & E 1.3 & 5.8 & 178 & $<2.0$ & 3.8 & 67.7 \\
\hline Gross alpha radioactivity, $\mathrm{pCi} / \mathrm{L}$ & $15^{\mathrm{a}, \mathrm{b}}$ & 0 & $<.58$ & $<1.1$ & 2.6 & $<.62$ & .7 & 4.9 \\
\hline Gross beta radioactivity, $\mathrm{pCi} / \mathrm{L}$ & $4 \mathrm{mrem} / \mathrm{yr}^{\mathrm{r}, \mathrm{b}}$ & -- & .7 & 1.6 & 5.0 & $<.86$ & 1.2 & 5.0 \\
\hline Radon-222, pCi/L & $300^{\mathrm{e}}$ & 17 & 57 & 600 & 1,130 & 22 & 222 & 1,140 \\
\hline
\end{tabular}

${ }^{a}$ U.S. Environmental Protection Agency Maximum Contaminant Level.

${ }^{b}$ New York State Department of Health Maximum Contaminant Level.

${ }^{\mathrm{c}}$ U.S. Environmental Protection Agency Secondary Maximum Contaminant Level.

${ }^{d}$ U.S. Environmental Protection Agency Treatment Technique.

${ }^{\mathrm{e}}$ U.S. Environmental Protection Agency Proposed Maximum Contaminant Level. 
however atrazine concentrations above the reporting level were present in the samples from three wells; the values ranged from 0.01 to $0.09 \mu \mathrm{g} / \mathrm{L}$. Alachlor was detected in one sample at an estimate of $0.002 \mu \mathrm{g} / \mathrm{L}$. Metalochlor was detected in one sample at $0.058 \mu \mathrm{g} / \mathrm{L}$. Prometon was detected below the LRL in samples from three wells and above the LRL in a sample from one well at a concentration of $0.01 \mu \mathrm{g} / \mathrm{L}$. Simazine was detected below the LRL at one well. No pesticide concentration exceeded Federal or New York State MCLs, and no Federal MCLs currently have been established for the pesticide degradation product CIAT. These trace-level detections of pesticides are similar to those reported by Eckhardt and others (2001), Phillips and others (1999), and Eckhardt and Stackelberg (1995) from studies of pesticides in groundwater throughout New York State.

\section{Volatile Organic Compounds}

Eight VOCs were detected in samples from six sand and gravel wells and two bedrock wells (table 1-8). None of the detected compounds exceeded State or Federal drinking-water standards. Trichloromethane, bromodichloromethane, dibromochloromethane, tribromomethane, 1,1,1-trichloroethane, 1,1-dichloroethane, and cis-1,2-dichloroethene were detected in samples from five production wells at concentrations ranging from 0.2 to $2.5 \mu \mathrm{g} / \mathrm{L}$. The first four compounds are trihalomethanes (THMs), which typically are formed as by-products when chlorine or bromine is used to disinfect water. The THMs were detected at three production wells. The State and Federal MCLs for total THMs $(80 \mu \mathrm{g} / \mathrm{L})$ were not exceeded. The three chlorinated solvents-1,1,1-trichloroethane, 1,1-dichloroethane, and cis-1,2-dichloroethene-were detected at two production wells. The NYSDOH MCL of $5 \mu \mathrm{g} / \mathrm{L}$ for these solvents was not exceeded. Toluene was detected in samples from three private residential wells at concentrations ranging from 0.1 to $0.2 \mu \mathrm{g} / \mathrm{L}$. One of the private residential wells was finished in sand and gravel and the other two private residential wells were finished in bedrock. The concentrations of toluene at these wells are below the NYSDOH MCL of $5 \mu \mathrm{g} / \mathrm{L}$.

\section{Bacteria}

All samples were analyzed for total coliform, fecal coliform, E. coli, and heterotrophic bacteria. Coliform bacteria were detected in nine samples, and fecal coliforms were detected in two samples (table 1-9). Coliform bacteria were detected in two samples from sand and gravel wells and in seven samples from bedrock wells. The NYSDOH and USEPA MCL violation for total coliform bacteria occurs when 5 percent of finished water samples collected in 1 month test positive for total coliform (if 40 or more samples are collected per month) or when 2 samples are positive for total coliform (if fewer than 40 samples are collected per month). Escherichia coli (E. coli) were detected in one bedrock well, exceeding the MCL. Heterotrophic plate counts (HPCs) ranged from less than 1 (absent) to 566 colony-forming units per milliliter (CFU/mL); the Federal MCL (500 CFU/mL) was exceeded in one sample.

\section{Wells Sampled in 2004 and 2009}

Six of the wells sampled as part of this study in 2009 (wells BM 90, BM 375, M 595, OG 6, OG 504, and OG 846) were sampled previously in 2004. Of the constituents and physical properties common to the 2004 and 2009 analyses, 54 were detected in both years for at least 1 of the 6 wells sampled (tables 1-10 through 1-13). The differences between 2004 and 2009 results for the same well were typically less than the results between different wells.

\section{Summary}

In 2002, the U.S. Geological Survey, in cooperation with the New York State Department of Environmental Conservation (NYSDEC), began an assessment of groundwater quality in bedrock and sand and gravel aquifers throughout New York State. As a part of this assessment, the Upper Susquehanna River Basin was studied in 2004 and again in 2009. The 2009 study is the subject of this report and includes analysis of 30 water samples collected from 16 production wells and 14 private residential wells from August through December 2009. Water samples were analyzed for 147 physical properties and constituents that included inorganic major ions, nutrients, organic carbon, trace elements, radon-222, gross alpha and gross beta radioactivities, select dissolved gases, pesticides, volatile organic compounds, and bacterial analyses. Six wells (BM 90, BM 375, M 595, OG 6, OG 504, and OG 846) were tested in both studies and a comparison was made of the results. The measurements for most of the constituents changed little between 2004 and 2009. No major changes were observed in the water quality of the six wells that were sampled in both years. 
The quality of the sampled groundwater generally was acceptable in 2004 and 2009. However, 28 of the 30 wells sampled in 2009 had at least 1 constituent that exceeded a Federal or New York State drinking-water standard. Recommended Maximum Contaminant Levels (MCL), Secondary Maximum Contaminant Levels, or Health Advisories set by the U.S.Environmental Protection Agency (USEPA) and New York State Department of Health were exceeded for trace elements (arsenic, manganese, and iron) at 10 wells, bacterial analyses (total and fecal coliform or both) at 9 wells, and residue on evaporation at 3 wells. The USEPA drinking-water advisory taste threshold was exceeded for one inorganic ion (sodium) at six wells. The USEPA proposed MCL for the radioactive isotope radon-222 was exceeded at 17 wells. Eight volatile organic chemicals (trichloromethane, bromodichloromethane, dibromochloromethane, tribromomethane, 1,1,1-trichloroethane, 1,1-dichloroethane, cis-1,2-dichloroethene, and toluene) were detected at five production wells (for which there are public reporting requirements) and three residential wells.

\section{References Cited}

American Public Health Association, 2005, Standard methods for the examination of water and wastewater (21st ed.): Washington, D.C., American Public Health Association, American Water Works Association, and Water Environment Federation [variously paged].

ASTM International, 2009, D5072-09(2009), Standard test method for radon in drinking water: ASTM International, accessed May 5, 2009, at http://www.astm.org.

Butch, G.K., Murray, P.M., Hebert, G.J., and Weigel, J.F., 2003, Water Resources Data, New York, Water Year 2002: U.S. Geological Survey Water-Data Report, NY-02-1, p. 502-520.

Childress, C.J.O., Foreman, W.T., Connor, B.F., and Maloney, T.J., 1999, New reporting procedures based on long-term method detection levels and some considerations for interpretations of water-quality data provided by the U.S. Geological Survey National Water Quality Laboratory: U.S. Geological Survey Open-File Report 99-193, 19 p.

Coates, D.R., 1966, Glaciated Appalachian Plateau—Till shadows on hills: Science, v. 152, p. 1,617-1,619.

Connor, B.F., Rose, D.L., Noriega, M.C., Murtagh, L.K., and Abney, S.R., 1998, Methods of analysis by the U.S. Geological Survey National Water Quality Laboratory-Determination of 86 volatile organic compounds in water by gas chromatography/mass spectrometry, including detections less than reporting limits: U.S. Geological Survey Open-File Report 97-829, 78 p.

Eckhardt, D.A., Hetcher, K.K., Phillips, P.J., and Miller, T.S., 2001, Pesticides and their metabolites in community watersupply wells of central and western New York, August 1999: U.S. Geological Survey Water-Resources Investigations Report $00-4128,12 \mathrm{p}$.

Eckhardt, D.A., Reddy, J.E., and Shaw, S.B., 2009, Groundwater quality in central New York, 2007: U.S. Geological Survey Open-File Report 2009-1257, 40 p., at http://pubs.usgs.gov/of/2009/1257/.

Eckhardt, D.A., Reddy, J.E., and Tamulonis, K.L., 2007, Ground-water quality in the Genesee River Basin, New York, 2005-06: U.S. Geological Survey Open-File Report 2007-1093, 26 p., at http://pubs.usgs.gov/of/2007/1093/.

Eckhardt, D.A., Reddy, J.E., and Tamulonis, K.L., 2008, Ground-water quality in western New York, 2006: U.S. Geological Survey Open-File Report 2008-1140, 36 p., at http://pubs.usgs.gov/of/2008/1140/.

Eckhardt, D.A. and Stackelberg, P.E., 1995, Relation of ground-water quality to land use of Long Island, New York: Ground Water, v. 33, no. 6, p. 1,019-1,033.

Fleisher, P.J., 1977a, Glacial geomorphology of upper Susquehanna drainage, in Wilson, P.C., ed., New York State Geological Association Guidebook: Oneonta, State University of New York, 49th Annual Meeting, p. A1-A10.

Fleisher, P.J., 1977b, Dead ice sinks and moats, environment of stagnant ice deposition: Geology, v. 14, p. 39-42.

Fleisher, P.J., 1986, Glacial geology and late Wisconsin stratigraphy, upper Susquehanna drainage basin, New York State, in Cadwell, D.H., ed., The Wisconsin stage of the first geological district, eastern New York: Albany, New York State Museum Bulletin 455, p. 121-142. 
Furlong, E.T., Anderson, B.D., Werner, S.L., Soliven, P.P., Coffey, L.J., and Burkhardt, M.R., 2001, Methods of analysis by the U.S. Geological Survey National Water Quality Laboratory-Determination of pesticides in water by graphitized carbonbased solid-phase extraction and high-performance liquid chromatography/mass spectrometry: U.S. Geological Survey WaterResources Investigations Report 01-4134, 73 p.

Garbarino, J.R., and Damrau, D.L., 2001, Methods of analysis by the U.S. Geological Survey National Water Quality Laboratory-Determination of organic plus inorganic mercury in filtered and unfiltered natural water with cold vapor-Atomic fluorescence spectrometry: U.S. Geological Survey Water-Resources Investigation Report 01-4132, 16 p.

Garbarino, J.R., Kanagy, L.K., and Cree, M.E., 2006, Determination of elements in natural-water, biota, sediment and soil samples using collision/reaction cell inductively coupled plasma-mass spectrometry: U.S. Geological Survey Techniques and Methods, book 5, sec. B, chap.1, 88 p.

Garbarino, J.R., and Struzeski, T.M., 1998, Methods of analysis by the U.S. Geological Survey National Water Quality Laboratory-Determination of elements in whole-water digests using inductively coupled plasma-optical emission spectrometry and inductively coupled plasma-mass spectrometry: U.S. Geological Survey Open-File Report 98-165, 101 p.

Hem, J.D., 1985, Study and interpretation of the chemical characteristics of natural water (3d ed.): U.S. Geological Survey Water-Supply Paper 2254, 264 p.

Hetcher-Aguila, K.K., 2005, Ground-water quality in the Chemung River Basin, New York, 2003: U.S. Geological Survey Open-File Report 04-1329, 19 p., at http://ny.water.usgs.gov/pubs/of/of041329/.

Hetcher-Aguila, K.K. and Eckhardt, D.A., 2006, Ground-water quality in the Upper Susquehanna River Basin, New York, 2004 05: U.S. Geological Survey Open-File Report 06-1161, 20 p., at http://pubs.usgs.gov/of/2006/1161/.

Hoffman, G.L., Fishman, M.J., and Garbarino, J.R., 1996, Methods of analysis by the U.S. Geological Survey National Water Quality Laboratory_-In-bottle acid digestion of whole-water samples: U.S. Geological Survey Open-File Report 96-225, 28 p.

Lee, E.A., and Strahan, A.P., 2003, Determination of acetamide herbicides and their degradation products in water using online solid-phase extraction and liquid chromatography/mass spectrometry: U.S. Geological Survey Open-File Report 03-173, 17 p.

MacNish, R.D., and Randall, A.D., 1982, Stratified-drift aquifers in the Susquehanna River basin, New York: Albany, New York State Department of Environmental Conservation Bulletin 75, 68 p.

Meyer, M.T., Mills, M.S., and Thurman, E.M., 1993, Automated solid-phase extraction of herbicides from water for gas chromatographic-mass spectrometric analysis: Journal of Chromatography, v. 629, p. 55-59.

New York State Department of Health, 2007, New York State Health Department public water systems regulations: Albany, N.Y. [variously paged], accessed January 2009, at http://www.health.state.ny.us/environmental/water/drinking/part5/tables.htm.

Nystrom, E.A., 2006, Ground-water quality in the Lake Champlain basin, New York, 2004: U.S. Geological Survey Open-File Report 06-1088, 22 p., at http://pubs.usgs.gov/of/2006/1088/.

Nystrom, E.A., 2007a, Ground-water quality in the St. Lawrence River basin, New York, 2005-2006: U.S. Geological Survey Open-File Report 2007-1066, 33 p., at http://pubs.usgs.gov/of/2007/1066/.

Nystrom, E.A., 2007b, Ground-water quality in the Delaware River basin, New York, 2001 and 2005-2006: U.S. Geological Survey Open-File Report 2007-1098, 36 p., at http://pubs.usgs.gov/of/2007/1098/.

Nystrom, E.A., 2008, Ground-water quality in the Mohawk River basin, New York, 2006: U.S. Geological Survey Open-File Report 2008-1086, 33 p., at http://pubs.usgs.gov/of/2008/1086/.

Nystrom, E.A., 2009, Ground-water quality in the Upper Hudson River basin, New York, 2007: U.S. Geological Survey OpenFile Report 2009-1240, 37 p., at http://pubs.usgs.gov/of/2009/1240/.

Nystrom, E.A., 2010, Groundwater quality in the Lower Hudson River basin, New York, 2008: U.S. Geological Survey OpenFile Report 2010-1197, 39 p., at http://pubs.usgs.gov/of/2010/1197/. 
Phillips, P.J., Eckhardt, D.A., Terracciano, S.A., and Rosenmann, L.R., 1999, Pesticides and their metabolites in wells of Suffolk County, New York, 1998: U.S. Geological Survey Water-Resources Investigations Report 99-4095, 12 p.

Randall, A.D., 2001, Hydrogeologic framework of stratified-drift aquifers in the glaciated Northeastern United States: U.S. Geological Survey Professional Paper 1415-B, 179 p.

Risen, A.J. and Reddy, J.E., 2011a, Groundwater quality in the Eastern Lake Ontario Basin, New York, 2008: U.S. Geological Survey Open-File Report 2011-1074, 32 p., at http://pubs.usgs.gov/of/2011/1074/.

Risen, A.J. and Reddy, J.E., 2011b, Groundwater quality in the Chemung River Basin, New York, 2008: U.S. Geological Survey Open-File Report 2011-1112, 25 p., at http://pubs.usgs.gov/of/2011/1112/.

Sandstrom, M.W., Stroppel, M.E., Foreman, W.T., and Schroeder, M.P., 2001, Methods of analysis by the U.S. Geological Survey National Water Quality Laboratory_-Determination of moderate-use pesticides and selected degradates in water by C-18 solid-phase extraction and gas chromatography/mass spectrometry: U.S. Geological Survey Water-Resources Investigations Report 01-4098, 70 p.

Shelton, L.R., 1994, Field guide for collecting and processing stream-water samples for the National Water-Quality Assessment Program: U.S. Geological Survey Open-File Report 94-455, 42 p.

Struzeski, T.M., DeGiacomo, W.J., and Zayhowski, E.J., 1996, Methods of analysis by the U.S. Geological Survey National Water Quality Laboratory-Determination of dissolved aluminum and boron in water by inductively coupled plasma-atomic emission spectrometry: U.S. Geological Survey Open-File Report 96-149, 17 p.

U.S. Environmental Protection Agency, 1980, Prescribed Procedures for Measurement of Radioactivity in Drinking Water: EPA 600/4-80-032. (Also available at http://www.epa.gov/ogwdw000/methods/pdfs/methods/methods_radionuclides.pdf.)

U.S. Environmental Protection Agency, 1997, Guidelines for preparation of the comprehensive state water quality assessments 305(b) reports and electronic updates: Washington, D.C., Office of Water, EPA 841-B-97-002A and EPA 841-B-97-002B, PL 95-217, $271 \mathrm{p}$.

U.S. Environmental Protection Agency, 1999, Proposed radon in drinking water rule: Washington, D.C., U.S. Environmental Protection Agency, Office of Water, EPA 815-F-99-006, 6 p.

U.S. Environmental Protection Agency, 2002, Drinking-water advisory—Consumer acceptability advice and health effects analysis on sodium: Washington, D.C., Office of Water, EPA 822-R-02-032, 34 p.

U.S. Environmental Protection Agency, 2009, National primary drinking water standards and national secondary drinking water standards: Washington, D.C., U.S. Environmental Protection Agency, Office of Water, EPA 816-F-09-0004, 6 p. (Also available at http://www.epa.gov/safewater/consumer/pdf/mcl.pdf.)

U.S. Geological Survey, [variously dated], National field manual for the collection of water-quality data: U.S. Geological Survey Techniques of Water-Resources Investigations, book 9, chapters A1-A9, available online at http://pubs.water.usgs.gov/twri9A.

Wilde, F.D., Radtke, D.B., Gibs, Jacob, and Iwatsubo, R.T., eds., 2004, Processing of water samples: U.S. Geological Survey Techniques of Water-Resources Investigations, book 9, chap. A5 [variously paged].

Zaugg, S.D., Sandstrom, M.W., Smith, S.G., and Fehlberg, K.M., 1995, Methods of analysis by the U.S. Geological Survey National Water Quality Laboratory - Determination of pesticides in water by C-18 solid-phase extraction and capillary-column gas chromatography with selective-ion monitoring: U.S. Geological Survey Open-File Report 95-181, 49 p. 


\section{Appendix}

Tables 1-1 Through 1-13 

Table 1-1. Information on wells sampled in the Upper Susquehanna River Basin, New York, 2009.

[Well locations are shown in figure 1; --, information not available; well types: P, production; D, domestic]

\begin{tabular}{|c|c|c|c|c|c|c|}
\hline Well number 1 & $\begin{array}{l}\text { U.S. Geological Survey } \\
\text { site identifier }\end{array}$ & Date sampled & $\begin{array}{c}\text { Well depth, } \\
\text { feet below land } \\
\text { surface }\end{array}$ & $\begin{array}{c}\text { Casing depth, } \\
\text { feet below land } \\
\text { surface }\end{array}$ & $\begin{array}{l}\text { Well } \\
\text { type }\end{array}$ & Bedrock type \\
\hline \multicolumn{7}{|c|}{ Sand and gravel wells } \\
\hline BM 90 & 420540076030701 & $9 / 21 / 2009$ & 145 & -- & $\mathrm{P}$ & -- \\
\hline BM 375 & 421954075583501 & $8 / 18 / 2009$ & 25 & 20 & $\mathrm{P}$ & -- \\
\hline C 1027 & 423453076074201 & $9 / 15 / 2009$ & 38 & 38 & $\mathrm{D}$ & -- \\
\hline $\mathrm{CN} 934$ & 424119075334501 & $11 / 16 / 2009$ & 60 & 50 & $\mathrm{P}$ & -- \\
\hline $\mathrm{CN} 935$ & 423916075462901 & $11 / 17 / 2009$ & 85 & 75 & $\mathrm{P}$ & -- \\
\hline CN 936 & 423244075311201 & $12 / 8 / 2009$ & 198.5 & 170 & $\mathrm{P}$ & -- \\
\hline CN 1065 & 422605075480301 & 9/30/2009 & 189 & 189 & $\mathrm{P}$ & -- \\
\hline CN 1142 & 421733075283601 & $12 / 8 / 2009$ & 205 & 191 & $\mathrm{P}$ & -- \\
\hline D 1450 & 422050075095701 & $11 / 23 / 2009$ & 80 & 70 & $\mathrm{P}$ & -- \\
\hline HE 1225 & 425304075111801 & $10 / 5 / 2009$ & 46 & 24 & $\mathrm{P}$ & -- \\
\hline OG 6 & 421918075191001 & $10 / 28 / 2009$ & 99 & 90 & $\mathrm{P}$ & -- \\
\hline OG 316 & 423938075024001 & $11 / 18 / 2009$ & 43.6 & 37 & $\mathrm{P}$ & -- \\
\hline OG 317 & 423241074491101 & $12 / 15 / 2009$ & 50 & 50 & $\mathrm{P}$ & -- \\
\hline TI 650 & 420049076314001 & $10 / 19 / 2009$ & 50 & 40 & $\mathrm{P}$ & -- \\
\hline TI 892 & 421350076110301 & $11 / 4 / 2009$ & 180 & -- & $\mathrm{P}$ & -- \\
\hline TI 1170 & 420710076225301 & $9 / 30 / 2009$ & 108 & 108 & $\mathrm{D}$ & -- \\
\hline \multicolumn{7}{|c|}{ Bedrock wells } \\
\hline BM 1841 & 420712075432301 & $9 / 21 / 2009$ & 60 & 20 & $\mathrm{D}$ & Shale and sandstone \\
\hline C 587 & 424430076014901 & $11 / 9 / 2009$ & 102 & 45 & $\mathrm{P}$ & Shale and sandstone \\
\hline C 1440 & 422452076140301 & $10 / 27 / 2009$ & 140 & 42 & $\mathrm{D}$ & Shale \\
\hline C 1486 & 422947075573901 & $9 / 15 / 2009$ & 180 & 50 & $\mathrm{D}$ & Shale \\
\hline CM 1293 & 421350076362401 & $10 / 14 / 2009$ & 220 & 29 & $\mathrm{D}$ & Shale \\
\hline CN 932 & 423354075414301 & $9 / 14 / 2009$ & 137 & -- & $\mathrm{D}$ & Shale \\
\hline CN 933 & 421529075470301 & $11 / 11 / 2009$ & 530 & 48 & $\mathrm{P}$ & Shale \\
\hline M 502 & 424928075315301 & $8 / 24 / 2009$ & 142 & 20 & $\mathrm{D}$ & Shale and sandstone \\
\hline M 595 & 424750075502401 & $9 / 28 / 2009$ & 359 & 63 & $\mathrm{D}$ & Shale \\
\hline OG 504 & 424604075110301 & 9/8/2009 & 109 & 57 & $\mathrm{D}$ & Shale and sandstone \\
\hline OG 846 & 424204074501901 & 9/9/2009 & 230 & 34 & $\mathrm{D}$ & Shale and sandstone \\
\hline OG 1054 & 422946075131501 & $9 / 2 / 2009$ & 313 & 16 & $\mathrm{D}$ & Shale and sandstone \\
\hline OG 1848 & 425036075014601 & $9 / 1 / 2009$ & 205 & 196 & $\mathrm{D}$ & Shale and sandstone \\
\hline SO 1335 & 423231074403301 & $8 / 26 / 2009$ & 97 & 21 & $\mathrm{D}$ & Shale and sandstone \\
\hline
\end{tabular}

1 Prefix denotes county: BM, Broome; C, Cortland; CM, Chemung; CN, Chenango; D, Delaware; HE, Herkimer;

M, Madison; OG, Otsego; SO, Schoharie; TI, Tioga; number is local well-identification number assigned by

U.S. Geological Survey. 
Table 1-2. Compounds for which groundwater samples from the Upper Susquehanna River Basin, New York were analyzed but not detected, 2009. -Continued

\begin{tabular}{|c|c|c|}
\hline $\begin{array}{l}\text { USGS parameter } \\
\text { code }\end{array}$ & Constituent & $\begin{array}{c}\text { Laboratory } \\
\text { reporting level, } \\
\text { micrograms per } \\
\text { liter }\end{array}$ \\
\hline \multicolumn{3}{|c|}{ Trace elements in unfiltered water } \\
\hline 01012 & Beryllium & $0.02-0.04$ \\
\hline 01059 & Thallium & .12 \\
\hline \multicolumn{3}{|c|}{ Pesticides in filtered water } \\
\hline 82660 & 2,6-Diethylaniline & .006 \\
\hline 49260 & Acetochlor & .01 \\
\hline 34253 & alpha-HCH & $.004-.008$ \\
\hline 82686 & Azinphos-methyl & .120 \\
\hline 82673 & Benfluralin & .014 \\
\hline 04028 & Butylate & $.002-.004$ \\
\hline 82680 & Carbaryl & $.06-.2$ \\
\hline 82674 & Carbofuran & .060 \\
\hline 38933 & Chlorpyrifos & .010 \\
\hline 82687 & cis-Permethrin & .014 \\
\hline 04041 & Cyanazine & $.022-.040$ \\
\hline 82682 & DCPA & $.006-.008$ \\
\hline 62170 & Desulfinyl fipronil & .012 \\
\hline 62169 & Desulfinylfipronil amide & .029 \\
\hline 39572 & Diazinon & .005 \\
\hline 39381 & Dieldrin & .009 \\
\hline 82677 & Disulfoton & $.04-.05$ \\
\hline 82668 & EPTC & .002 \\
\hline 82663 & Ethalfluralin & $.006-.009$ \\
\hline 82672 & Ethoprop & .016 \\
\hline 62167 & Fipronil sulfide & .013 \\
\hline 62168 & Fipronil sulfone & .024 \\
\hline 62166 & Fipronil & $.018-.040$ \\
\hline 04095 & Fonofos & $.004-.010$ \\
\hline 39341 & Lindane & $.004-.014$ \\
\hline 82666 & Linuron & .06 \\
\hline 39532 & Malathion & $.016-.020$ \\
\hline 82667 & Methyl parathion & .008 \\
\hline 82630 & Metribuzin & $.012-.016$ \\
\hline 82671 & Molinate & $.002-.003$ \\
\hline 82684 & Napropamide & $.008-.018$ \\
\hline 34653 & $p, p^{\prime}-\mathrm{DDE}$ & $.002-.003$ \\
\hline 39542 & Parathion & .020 \\
\hline 82669 & Pebulate & .016 \\
\hline 82683 & Pendimethalin & .012 \\
\hline 82664 & Phorate & .020 \\
\hline
\end{tabular}


Table 1-2. Compounds for which groundwater samples from the Upper Susquehanna River Basin, New York were analyzed but not detected, 2009. -Continued

\begin{tabular}{|c|c|c|}
\hline 04024 & Propachlor & $.006-.012$ \\
\hline 82679 & Propanil & $.010-.014$ \\
\hline 82685 & Propargite & .02 \\
\hline 82676 & Propyzamide & .004 \\
\hline 82670 & Tebuthiron & $.02-.03$ \\
\hline 82665 & Terbacil & $.024-.040$ \\
\hline 82675 & Terbufos & .02 \\
\hline 82681 & Thiobencarb & .016 \\
\hline 82678 & Triallate & .006 \\
\hline 82661 & Trifluralin & $.012-.018$ \\
\hline \multicolumn{3}{|c|}{ Volatile organic compounds, in unfiltered water } \\
\hline 77652 & 1,1,1-Trichloro-1,2,2-trifluoroethane & .1 \\
\hline 34501 & 1,1-Dichloroethene & .1 \\
\hline 34536 & 1,2-Dichlorobenzene & .1 \\
\hline 32103 & 1,2-Dichloroethane & .2 \\
\hline 34541 & 1,2-Dichloropropane & .1 \\
\hline 34566 & 1,3-Dichlorobenzene & .1 \\
\hline 34571 & 1,4-Dichlorobenzene & .1 \\
\hline 34030 & Benzene & .1 \\
\hline 34301 & Chlorobenzene & .1 \\
\hline 34668 & Dichlorodifluoromethane & .2 \\
\hline 34423 & Dichloromethane & .2 \\
\hline 81576 & Diethyl ether & .2 \\
\hline 81577 & Diisopropyl ether & .2 \\
\hline 34371 & Ethylbenzene & .1 \\
\hline 78032 & Methyl tert-butyl ether & .2 \\
\hline 50005 & Methyl tert-pentyl ether & .2 \\
\hline 85795 & $m+p$ Xylene & .2 \\
\hline 77135 & o-Xylene & .1 \\
\hline 77128 & Styrene & .1 \\
\hline 50004 & tert-Butyl ethyl ether & .1 \\
\hline 34475 & Tetrachloroethene & .1 \\
\hline 32102 & Tetrachloromethane & .2 \\
\hline 34546 & trans-1,2-Dichloroethene & .1 \\
\hline 39180 & Trichloroethene & .1 \\
\hline 34488 & Trichlorofluoromethane & .2 \\
\hline 39175 & Vinyl Choride & .2 \\
\hline
\end{tabular}


Table 1-3. Physical properties of groundwater samples from the Upper Susquehanna River Basin, New York, 2009.

[Well locations are shown in figure 1 (00080), National Water Information System (NWIS) parameter code; $\mu \mathrm{S} / \mathrm{cm}$, microsiemens per centimeter at $25^{\circ} \mathrm{C}$; $\mathrm{mg} / \mathrm{L}$, milligrams per liter; $<$, less than. Bold values exceed one or more drinking-water standard]

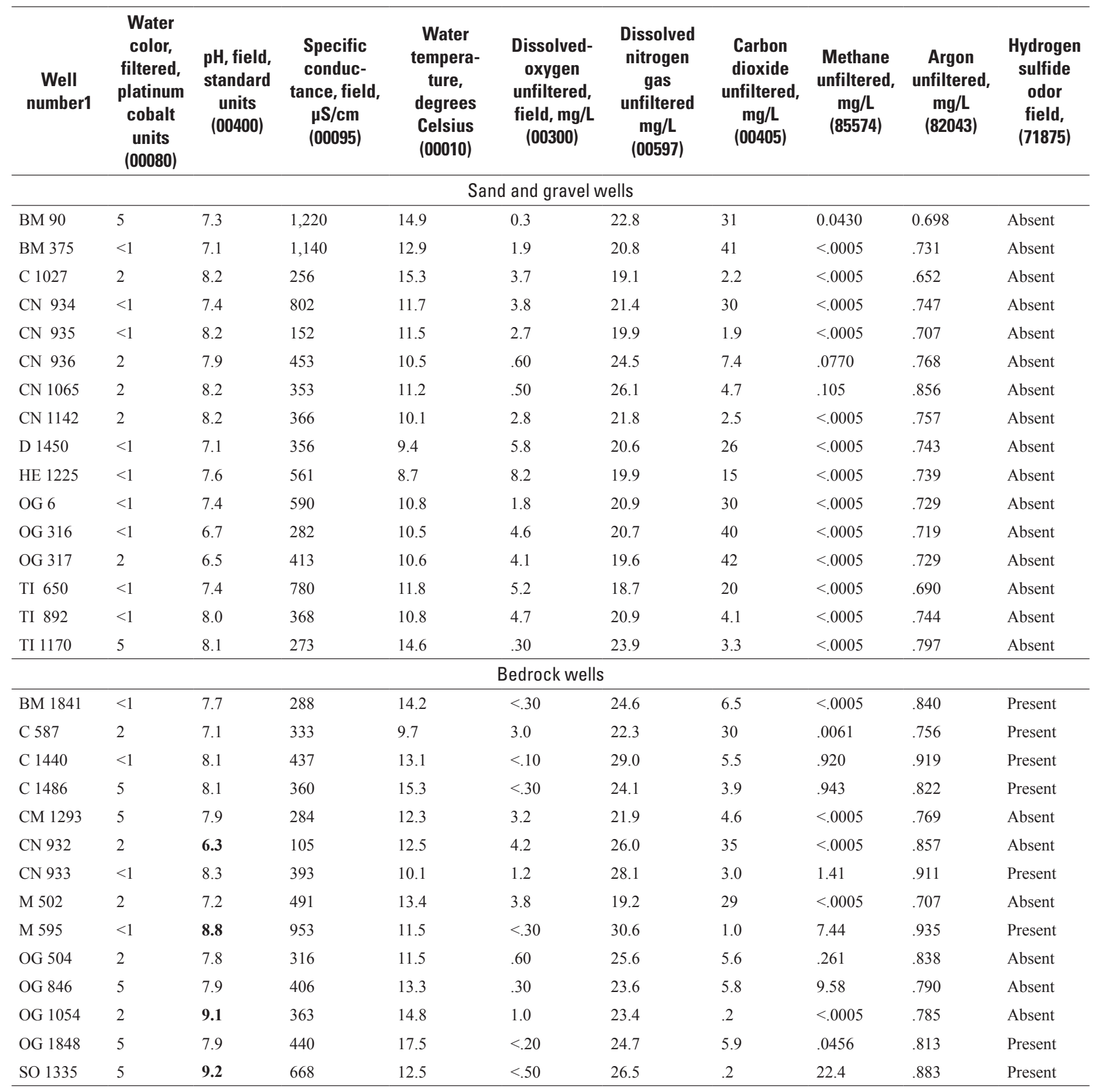

${ }^{1}$ Prefix denotes county: BM, Broome; C, Cortland; CM, Chemung; CN, Chenango; D, Delaware; HE, Herkimer; M, Madison; OG, Otsego; SO, Schoharie; TI, Tioga. Number is local well-identification number assigned by U.S. Geological Survey. 
Table 1-4. Concentrations of major ions in groundwater samples from the Upper Susquehanna River Basin, New York, 2009.

[Well locations are shown in figure 1. mg/L, milligrams per liter; $\mathrm{CaCO}_{3}$, calcium carbonate; (29805), USGS National Water Information System (NWIS) parameter code; E, estimated value - constituent was detected in the sample but with low or inconsistent recovery; $<$, less than. Bold values exceed one or more drinking-water standard]

\begin{tabular}{|c|c|c|c|c|c|c|c|}
\hline $\begin{array}{c}\text { Well } \\
\text { number }{ }^{1}\end{array}$ & $\begin{array}{l}\text { Hardness, } \\
\text { filtered, } \\
\text { mg/L as } \\
\mathrm{CaCO}_{3} \\
(\mathbf{0 0 9 0 0 )}\end{array}$ & $\begin{array}{c}\text { Calcium, } \\
\text { filtered, } \\
\text { mg/L } \\
(00915)\end{array}$ & $\begin{array}{c}\text { Magnesium, } \\
\text { filtered, } \\
\text { mg/L } \\
(00925)\end{array}$ & $\begin{array}{c}\text { Potassium, } \\
\text { filtered, } \\
\text { mg/L } \\
\text { (00935) }\end{array}$ & $\begin{array}{c}\text { Sodium, } \\
\text { filtered, } \\
\text { mg/L } \\
(00930)\end{array}$ & $\begin{array}{l}\text { Acid-neutral- } \\
\text { izing } \\
\text { capacity, } \\
\text { unfiltered, } \\
\text { mg/L as CaCO } \\
\text { (90410) }\end{array}$ & $\begin{array}{c}\text { Alkalinity, }{ }^{2} \\
\text { filtered, } \\
\text { mg/L as } \\
\mathrm{CaCO}_{3} \\
(29801)\end{array}$ \\
\hline \multicolumn{8}{|c|}{ Sand and gravel wells } \\
\hline BM 90 & 400 & 128 & 20.3 & 2.14 & 70.4 & 269 & 270 \\
\hline BM 375 & 310 & 102 & 14.6 & 1.37 & 99.7 & 265 & 266 \\
\hline C 1027 & 110 & 35.1 & 4.57 & .82 & 6.69 & 106 & 106 \\
\hline CN 934 & 290 & 97.0 & 11.2 & 3.75 & 48.6 & 265 & 265 \\
\hline CN 935 & 68 & 23.0 & 2.62 & .63 & 1.96 & 60 & 60 \\
\hline CN 936 & 190 & 56.3 & 13.1 & .81 & 13.2 & 166 & 167 \\
\hline CN 1065 & 140 & 41.5 & 7.65 & .60 & 22.8 & 183 & 184 \\
\hline CN 1142 & 130 & 44.8 & 5.38 & 1.19 & 14.3 & 108 & 108 \\
\hline D 1450 & 120 & 38.8 & 6.14 & 1.00 & 16.4 & 60 & 60 \\
\hline HE 1225 & 230 & 79.4 & 7.85 & 2.12 & 17.8 & 209 & 209 \\
\hline OG 6 & 250 & 86.5 & 7.09 & 1.80 & 23.4 & 202 & 202 \\
\hline OG 316 & 65 & 21.8 & 2.67 & 2.09 & 27.2 & 63 & 63 \\
\hline OG 317 & 82 & 24.0 & 5.34 & 1.30 & 37.3 & 38 & 38 \\
\hline TI 650 & 290 & 91.1 & 16.0 & 1.33 & 40.8 & 213 & 216 \\
\hline TI 892 & 150 & 46.6 & 8.00 & .98 & 15.6 & 129 & 129 \\
\hline TI 1170 & 120 & 37.5 & 5.31 & .58 & 10.4 & 113 & 113 \\
\hline \multicolumn{8}{|c|}{ Bedrock wells } \\
\hline BM 1841 & 120 & 33.7 & 8.46 & 1.50 & 12.6 & 139 & 138 \\
\hline C 587 & 140 & 49.8 & 3.64 & .48 & 13.5 & 157 & 158 \\
\hline C 1440 & 140 & 39.5 & 10.3 & .51 & 41.4 & 210 & 211 \\
\hline C 1486 & 110 & 31.2 & 7.67 & .71 & 32.3 & 180 & 181 \\
\hline CM 1293 & 82 & 25.2 & 4.64 & .53 & 24.3 & 128 & 128 \\
\hline CN 932 & 44 & 14.5 & 2.00 & .3 & 2.96 & 36 & 37 \\
\hline CN 933 & 73 & 21.1 & 5.00 & .73 & 50.3 & 178 & 179 \\
\hline M 502 & 230 & 81.9 & 5.30 & .38 & 12.8 & 236 & 235 \\
\hline M 595 & 58 & 18.8 & 2.80 & .50 & 170 & 200 & 199 \\
\hline OG 504 & 120 & 38.3 & 7.00 & .46 & 17.2 & 158 & 156 \\
\hline OG 846 & 40 & 12.2 & 2.23 & .55 & 70.7 & 117 & 129 \\
\hline OG 1054 & 7 & 2.21 & .424 & .23 & 77.1 & 149 & 154 \\
\hline OG 1848 & 130 & 35.2 & 9.04 & 1.35 & 46.4 & 192 & 197 \\
\hline SO 1335 & 16 & 4.29 & 1.18 & .38 & 127 & 192 & 191 \\
\hline
\end{tabular}

${ }^{1}$ Prefix denotes county: BM, Broome; C, Cortland; CM, Chemung; CN, Chenango; D, Delaware; HE, Herkimer; M, Madison; OG, Otsego; SO, Schoharie; TI, Tioga. Number is local well-identification number assigned by U.S. Geological Survey.

${ }^{2}$ Fixed-endpoint titration at $\mathrm{pH} 4.5$.

${ }^{3}$ Calculated from alkalinity. 
Table 1-4. Concentrations of major ions in groundwater samples from the Upper Susquehanna River Basin, New York, 2009.Continued

[Well locations are shown in figure 1. mg/L, milligrams per liter; $\mathrm{CaCO}_{3}$, calcium carbonate; (29805), USGS National Water Information System (NWIS) parameter code; E, estimated value — constituent was detected in the sample but with low or inconsistent recovery; <, less than. Bold values exceed one or more drinking-water standard]

\begin{tabular}{|c|c|c|c|c|c|c|}
\hline $\begin{array}{c}\text { Well } \\
\text { number }{ }^{1}\end{array}$ & $\begin{array}{c}\text { Bicarbonate, }^{3} \\
\text { filtered, } \\
\text { mg/L } \\
(29805)\end{array}$ & $\begin{array}{c}\text { Chloride, } \\
\text { filtered, } \\
\text { mg/L } \\
(00940)\end{array}$ & $\begin{array}{c}\text { Fluoride, } \\
\text { filtered, } \\
\text { mg/L } \\
(00950)\end{array}$ & $\begin{array}{c}\text { Silica, } \\
\text { filtered, } \\
\text { mg/L } \\
(00955)\end{array}$ & $\begin{array}{c}\text { Sulfate, } \\
\text { filtered, } \\
\text { mg/L } \\
(00945)\end{array}$ & $\begin{array}{c}\text { Residue on } \\
\text { evaporation, } \\
\text { at } 180^{\circ} \text { Celsius, } \\
\text { filtered, } \\
\mathrm{mg} / \mathrm{L} \\
(70300)\end{array}$ \\
\hline \multicolumn{7}{|c|}{ Sand and gravel wells } \\
\hline C 1027 & 129 & 11.5 & E.05 & 6.02 & 6.34 & 143 \\
\hline CN 934 & 323 & 79.7 & $<.08$ & 7.10 & 17.2 & 456 \\
\hline CN 935 & 73 & 1.97 & $<.08$ & 5.40 & 8.55 & 83 \\
\hline CN 936 & 204 & 26.2 & .08 & 11.1 & 27.7 & 253 \\
\hline HE 1225 & 255 & 32.3 & E.06 & 4.76 & 21.5 & 306 \\
\hline OG 6 & 246 & 42.5 & E.06 & 8.01 & 18.8 & 334 \\
\hline OG 316 & 77 & 34.3 & .10 & 5.56 & 10.4 & 144 \\
\hline OG 317 & 46 & 88.1 & $<.08$ & 5.61 & 11.4 & 212 \\
\hline TI 650 & 264 & 99.3 & .09 & 8.51 & 16.8 & 419 \\
\hline TI 892 & 157 & 26.3 & $<.08$ & 6.05 & 9.79 & 195 \\
\hline TI 1170 & 138 & 9.80 & .21 & 10.8 & 12.2 & 146 \\
\hline \multicolumn{7}{|c|}{ Bedrock wells } \\
\hline BM 1841 & 168 & .71 & .20 & 14.3 & 12.4 & 173 \\
\hline CN 933 & 218 & 5.28 & .32 & 11.1 & 6.70 & 201 \\
\hline M 502 & 287 & 6.30 & E. 08 & 5.78 & 12.1 & 269 \\
\hline M 595 & 243 & 176 & .74 & 7.71 & 2.48 & 506 \\
\hline OG 504 & 190 & 4.90 & .11 & 12.3 & 3.56 & 178 \\
\hline OG 846 & 157 & 48.5 & .34 & 7.06 & 3.14 & 231 \\
\hline OG 1054 & 188 & 17.0 & .43 & 7.57 & 7.60 & 212 \\
\hline OG 1848 & 240 & 1.54 & .25 & 9.10 & 33.9 & 263 \\
\hline SO 1335 & 233 & 88.0 & .34 & 7.71 & E. 17 & 368 \\
\hline
\end{tabular}

${ }^{1}$ Prefix denotes county: BM, Broome; C, Cortland; CM, Chemung; CN, Chenango; D, Delaware; HE, Herkimer; M, Madison; OG, Otsego; SO, Schoharie; TI, Tioga. Number is local well-identification number assigned by U.S. Geological Survey.

${ }^{2}$ Fixed-endpoint titration at $\mathrm{pH} 4.5$.

${ }^{3}$ Calculated from alkalinity. 
Table 1-5. Concentrations of nutrients and total organic carbon in groundwater samples from the Upper Susquehanna River Basin, New York, 2009.

[Well locations are shown in figure 1. mg/L, milligrams per liter; N, nitrogen; (00623), National Water Information System (NWIS) parameter code; P, phosphorus; <, less than; E, estimated value — constituent was detected in the sample but with low or inconsistent recovery]

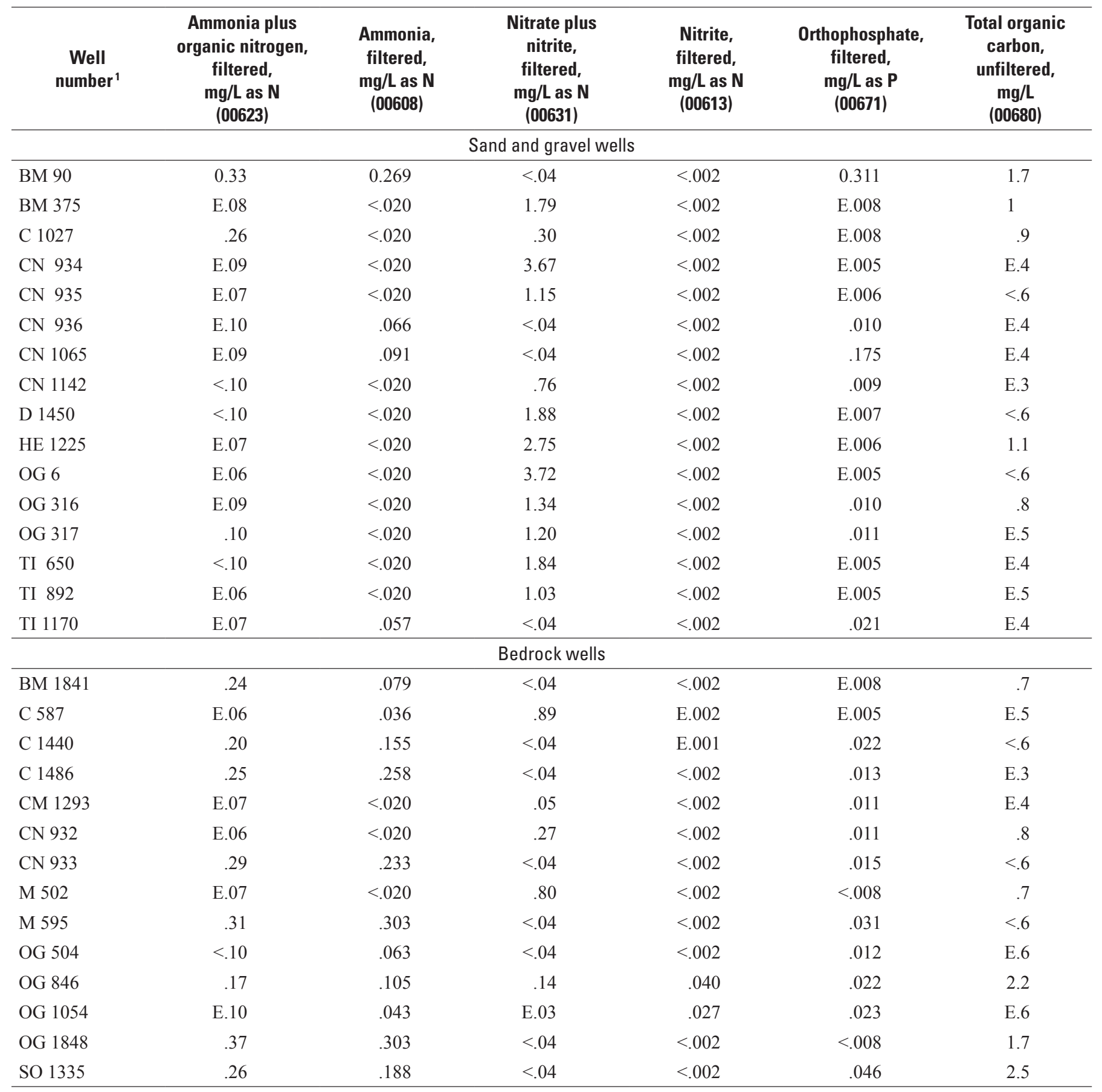

${ }^{1}$ Prefix denotes county: BM, Broome; C, Cortland; CM, Chemung; CN, Chenango; D, Delaware; HE, Herkimer; M, Madison; OG, Otsego; SO, Schoharie; TI, Tioga. Number is local well-identification number assigned by U.S. Geological Survey. 
Table 1-6. Concentrations of trace elements and radiochemicals in groundwater samples from the Upper Susquehanna River Basin, New York, 2009.

[Well locations are shown in figure 1. pCi/L, picocuries per liter; $\mu \mathrm{g} / \mathrm{L}$, micrograms per liter; (01105), USGS National Water Information System (NWIS) parameter code; <, less than;

E, estimated value - constituent was detected in the sample but with low or inconsistent recovery. Bold values exceed one or more drinking-water standard]

\begin{tabular}{|c|c|c|c|c|c|c|c|c|c|}
\hline $\begin{array}{c}\text { Well } \\
\text { number }^{1}\end{array}$ & $\begin{array}{c}\text { Aluminum, } \\
\text { unfiltered, } \\
\mu \mathrm{g} / \mathrm{L} \text { (01105) }\end{array}$ & $\begin{array}{c}\text { Antimony, } \\
\text { unfiltered, } \\
\mu \mathrm{g} / \mathrm{L}(01097)\end{array}$ & $\begin{array}{c}\text { Arsenic, } \\
\text { unfiltered, } \\
\mu \mathrm{g} / \mathrm{L}(01002)\end{array}$ & $\begin{array}{c}\text { Barium, } \\
\text { unfiltered, } \\
\mu \mathrm{g} / \mathrm{L}(01007)\end{array}$ & $\begin{array}{c}\text { Boron, } \\
\text { filtered, } \\
\mu \mathrm{g} / \mathrm{L}(01020)\end{array}$ & $\begin{array}{c}\text { Cadmium, } \\
\text { unfiltered, } \\
\text { pg/L (01027) }\end{array}$ & $\begin{array}{l}\text { Chromium, } \\
\text { unfiltered, } \\
\mu \mathrm{g} / \mathrm{L}(01034)\end{array}$ & $\begin{array}{c}\text { Cobalt, } \\
\text { unfiltered, } \\
\mu \mathrm{g} / \mathrm{L}(01037)\end{array}$ & $\begin{array}{c}\text { Copper, } \\
\text { unfiltered, } \\
\text { pg/L (01042) }\end{array}$ \\
\hline \multicolumn{10}{|c|}{ Sand and gravel wells } \\
\hline BM 90 & $<6$ & $<.4$ & 9.7 & 640 & 37 & $<.06$ & $<.40$ & E.09 & E3.2 \\
\hline BM 375 & $<6$ & $<.4$ & 1.6 & 72.5 & 38 & $<.06$ & E. 30 & E.09 & $<4.0$ \\
\hline C 1027 & $<6$ & $<.4$ & .61 & 15.6 & 9.1 & $<.06$ & $<.40$ & $<.10$ & $<4.0$ \\
\hline CN 934 & $<6$ & $<.4$ & .45 & 57.6 & 28 & $<.04$ & E. 33 & .08 & 34.9 \\
\hline CN 935 & E3 & $<.4$ & .26 & 14.7 & 7.6 & $<.04$ & $<.42$ & $<.04$ & 2.7 \\
\hline CN 936 & $<6$ & $<.4$ & .98 & 111 & 23 & $<.04$ & $<.42$ & .04 & 2.8 \\
\hline CN 1065 & $<6$ & $<.4$ & 18.4 & 482 & 87 & $<.06$ & $<.40$ & $<.10$ & E2.0 \\
\hline CN 1142 & $<6$ & E. 2 & 1.2 & 149 & 22 & $<.04$ & $<.42$ & E.02 & 51.5 \\
\hline D 1450 & $<6$ & $<.4$ & .36 & 117 & 11 & $<.04$ & $<.42$ & E.04 & 13.0 \\
\hline HE 1225 & $<6$ & $<.4$ & 1.2 & 49.1 & 20 & $<.04$ & E. 23 & .04 & E1.3 \\
\hline OG 6 & $<6$ & $<.4$ & .66 & 112 & 39 & $<.04$ & $<.42$ & .13 & 3.5 \\
\hline OG 316 & $<6$ & $<.4$ & .29 & 5.7 & 13 & $<.04$ & $<.42$ & E. 03 & 4.7 \\
\hline OG 317 & $<6$ & $<.4$ & .25 & 8.1 & 14 & .07 & $<.42$ & E.04 & E.93 \\
\hline TI 650 & 6 & $<.4$ & .56 & 148 & 22 & $<.04$ & E. 22 & .06 & 4.3 \\
\hline TI 892 & 24 & $<.4$ & .44 & 34.1 & 9.7 & $<.04$ & E. 32 & $<.04$ & E1.0 \\
\hline TI 1170 & $<6$ & $<.4$ & .93 & 29.1 & 16 & $<.06$ & $<.40$ & $<.10$ & $<4.0$ \\
\hline \multicolumn{10}{|c|}{ Bedrock wells } \\
\hline BM 1841 & $<6$ & $<.4$ & 1.2 & 116 & 104 & $<.06$ & $<.40$ & $<.10$ & 4.7 \\
\hline C 587 & 30 & $<.4$ & .61 & 92.9 & 73 & $<.04$ & E. 31 & .11 & 2.9 \\
\hline C 1440 & $<6$ & $<.4$ & .57 & 169 & 237 & .04 & $<.42$ & $<.04$ & 22.3 \\
\hline C 1486 & $<6$ & $<.4$ & .43 & 944 & 236 & $<.06$ & $<.40$ & $<.10$ & $<4.0$ \\
\hline CM 1293 & 59 & $<.4$ & .56 & 150 & 126 & $<.04$ & $<.42$ & .06 & 5.8 \\
\hline CN 932 & $<6$ & $<.4$ & .32 & 23.5 & 4.1 & $<.06$ & $<.40$ & $<.10$ & 267 \\
\hline CN 933 & E5 & $<.4$ & E.18 & 356 & 308 & $<.04$ & $<.42$ & $<.04$ & 25.4 \\
\hline M 502 & $<6$ & $<.4$ & .93 & 53.8 & 69 & $<.06$ & $<.40$ & $<.10$ & E3.8 \\
\hline M 595 & E4 & $<.4$ & .29 & 722 & 732 & $<.06$ & $<.40$ & $<.10$ & $<4.0$ \\
\hline OG 504 & $<6$ & $<.4$ & .79 & 66.5 & 156 & $<.06$ & $<.40$ & $<.10$ & $<4.0$ \\
\hline OG 846 & 8 & $<.4$ & .58 & 44.2 & 401 & $<.06$ & $<.40$ & $<.10$ & 6.2 \\
\hline OG 1054 & 57 & $<.4$ & 5.1 & 14.6 & 287 & $<.06$ & E. 31 & $<.10$ & E2.4 \\
\hline OG 1848 & $<6$ & $<.4$ & .39 & 62.7 & 551 & $<.06$ & $<.40$ & $<.10$ & 17.4 \\
\hline SO 1335 & 11 & $<.4$ & E.11 & 80.4 & 537 & $<.06$ & $<.40$ & $<.10$ & 11.5 \\
\hline
\end{tabular}


Table 1-6. Concentrations of trace elements and radiochemicals in groundwater samples from the Upper Susquehanna River Basin, New York, 2009.-Continued

[Well locations are shown in figure 1. $\mu \mathrm{g} / \mathrm{L}$, micrograms per liter; (01105), USGS National Water Information System (NWIS) parameter code; <, less than; E, estimated value — constituent was detected in the sample but with low or inconsistent recovery. Bold values exceed one or more drinking-water standard]

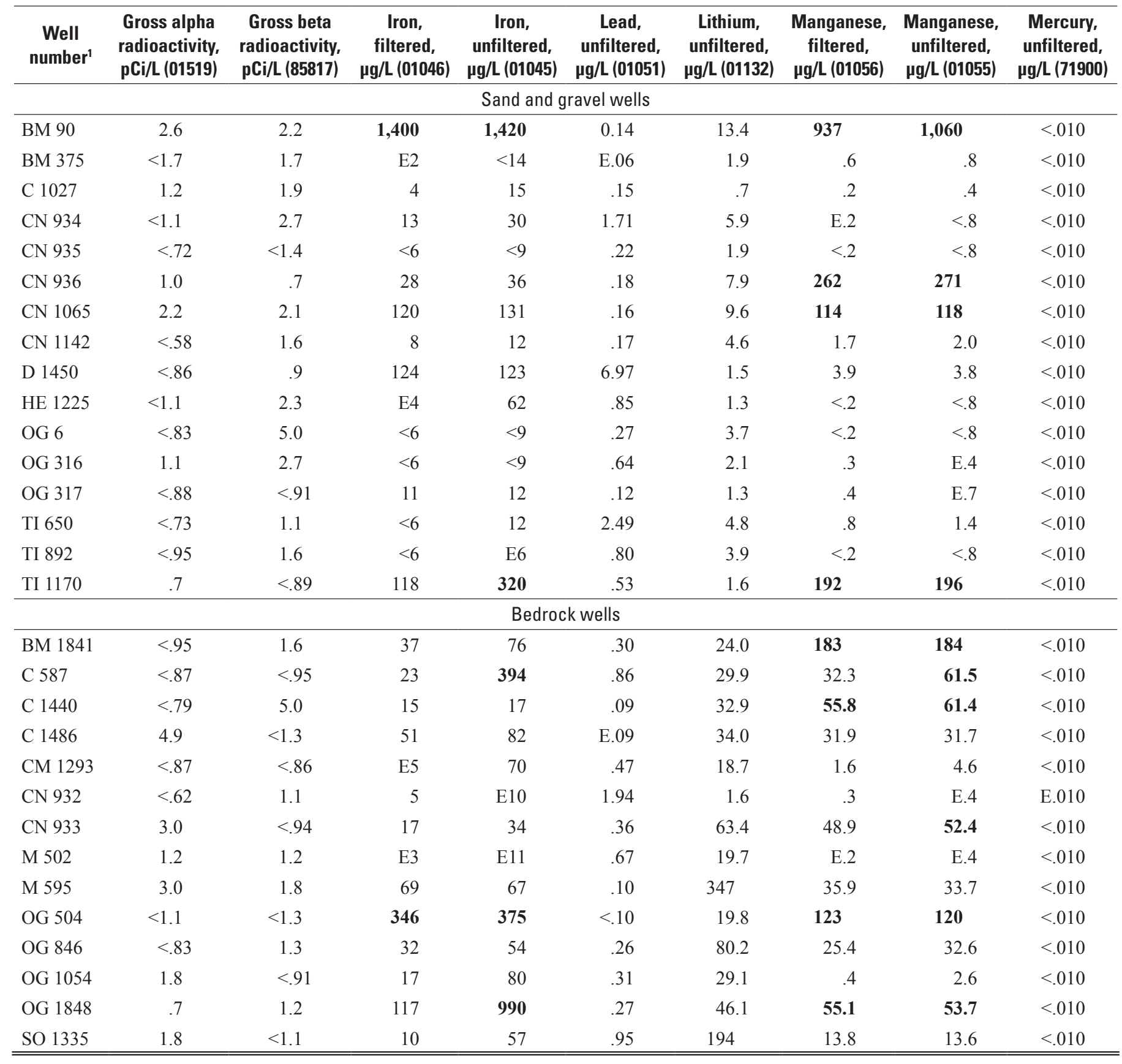


Table 1-6. Concentrations of trace elements and radiochemicals in groundwater samples from the Upper Susquehanna River Basin, New York, 2009.-Continued

[Well locations are shown in figure 1. $\mu \mathrm{g} / \mathrm{L}$, micrograms per liter; (01105), USGS National Water Information System (NWIS) parameter code; <, less than; E, estimated value - constituent was detected in the sample but with low or inconsistent recovery. Bold values exceed one or more drinking-water standard]

\begin{tabular}{|c|c|c|c|c|c|c|c|c|}
\hline $\begin{array}{c}\text { Well } \\
\text { number }^{1}\end{array}$ & $\begin{array}{c}\text { Molybdenum, } \\
\text { unfiltered, } \\
\text { } \mu \mathrm{g} / \mathrm{L} \text { (01062) }\end{array}$ & $\begin{array}{c}\text { Nickel, } \\
\text { unfiltered, } \\
\text { pg/L (01067) }\end{array}$ & $\begin{array}{c}\text { Selenium, } \\
\text { unfiltered, } \\
\text { pg/L (01147) }\end{array}$ & $\begin{array}{c}\text { Silver, } \\
\text { unfiltered, } \\
\text { lg/L (01077) }\end{array}$ & $\begin{array}{c}\text { Strontium, } \\
\text { unfiltered, } \\
\text { pg/L (01082) }\end{array}$ & $\begin{array}{c}\text { Radon-222, } \\
\text { unfiltered, } \\
\text { pCi/L (82303) }\end{array}$ & $\begin{array}{c}\text { Uranium, } \\
\text { unfiltered, } \\
\text { pg/L (28011) }\end{array}$ & $\begin{array}{c}\text { Zinc, } \\
\text { unfiltered, } \\
\mu \mathrm{g} / \mathrm{L}(01092)\end{array}$ \\
\hline \multicolumn{9}{|c|}{ Sand and gravel wells } \\
\hline BM 90 & 0.4 & 0.78 & $<.12$ & $<.06$ & 394 & 276 & 1.120 & 7.5 \\
\hline BM 375 & E.1 & .59 & .30 & $<.06$ & 157 & 780 & .755 & 3.9 \\
\hline C 1027 & $<.1$ & $<.20$ & $<.12$ & $<.06$ & 54.0 & 520 & .094 & 9.6 \\
\hline CN 935 & $<.1$ & E.34 & E.06 & $<.02$ & 43.0 & 600 & .033 & 4.0 \\
\hline CN 936 & .3 & E. 25 & $<.10$ & $<.02$ & 444 & 135 & .619 & E1.8 \\
\hline CN 1065 & .6 & E. 12 & $<.12$ & $<.06$ & 271 & 57 & .044 & 2.8 \\
\hline CN 1142 & .2 & E. 35 & 0.23 & $<.02$ & 89.7 & 890 & .721 & 7.4 \\
\hline OG 316 & .1 & E. 20 & E.06 & $<.02$ & 58.5 & 880 & .114 & E1.3 \\
\hline OG 317 & $<.1$ & 1.8 & E.10 & $<.02$ & 74.7 & 700 & $<.028$ & 24.3 \\
\hline TI 650 & E.1 & .62 & .19 & $<.02$ & 128 & 590 & .193 & 3.6 \\
\hline TI 892 & $<.1$ & $<.36$ & $<.10$ & $<.02$ & 78.8 & 620 & .099 & 18.5 \\
\hline TI 1170 & .7 & E.15 & $<.12$ & $<.06$ & 146 & 370 & .574 & 178 \\
\hline \multicolumn{9}{|c|}{ Bedrock wells } \\
\hline BM 1841 & .4 & 1.3 & $<.12$ & $<.06$ & 901 & $\mathbf{5 5 0}$ & .027 & 24.1 \\
\hline C 587 & E.1 & .38 & E.07 & $<.02$ & 268 & 560 & .171 & 10.0 \\
\hline C 1440 & .2 & $<.36$ & $<.10$ & $<.02$ & 1,030 & 70 & .057 & E1.9 \\
\hline OG 504 & .4 & $<.20$ & $<.12$ & $<.06$ & 324 & 192 & .072 & 6.4 \\
\hline OG 846 & .1 & E.14 & $<.12$ & $<.06$ & 284 & 175 & E.014 & 2.4 \\
\hline OG 1054 & 5.0 & E.13 & $<.12$ & $<.06$ & 38.7 & 1,140 & .574 & 4.3 \\
\hline OG 1848 & 3.0 & .31 & $<.12$ & $<.06$ & 848 & 22 & E. 018 & E1.8 \\
\hline SO 1335 & .1 & $<.20$ & $<.12$ & $<.06$ & 258 & 320 & $<.020$ & E1.4 \\
\hline
\end{tabular}

${ }^{1}$ Prefix denotes county: BM, Broome; C, Cortland; CM, Chemung; CN, Chenango; D, Delaware; HE, Herkimer; M, Madison; OG, Otsego; SO, Schoharie; TI, Tioga. Number is local well-identification number assigned by U.S. Geological Survey. 
Table 1-7. Concentrations of pesticides detected in groundwater samples from the Upper Susquehanna River Basin, New York, 2009.

[Well locations are shown in figure 1. CIAT, 2-Chloro-4-isopropylamino-6-amino-s-triazine; $\mu \mathrm{g} / \mathrm{L}$, micrograms per liter; (04040), USGS National Water Information System (NWIS) parameter code; <, less than; E, estimated value — constituent was detected in the sample but with low or inconsistent recovery; --, no data; $M$, measured but not quantified]

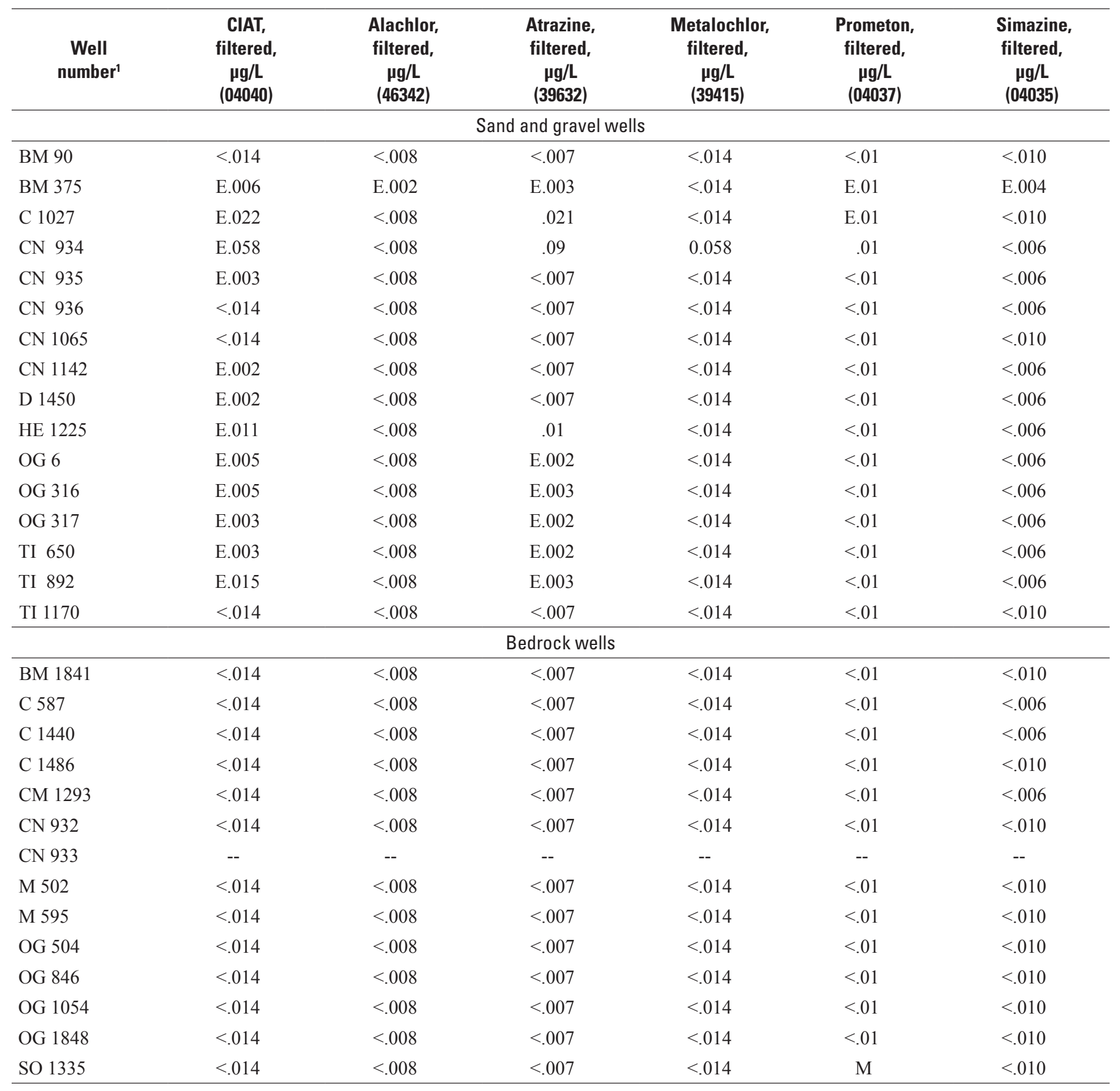

${ }^{1}$ Prefix denotes county: BM, Broome; C, Cortland; CM, Chemung; CN, Chenango; D, Delaware; HE, Herkimer; M, Madison; OG, Otsego; SO, Schoharie; TI, Tioga. Number is local well-identification number assigned by U.S. Geological Survey. 
Table 1-8. Concentrations of volatile organic compounds in groundwater samples from the Upper Susquehanna River Basin, New York, 2009.

[ Well locations are shown in figure 1. $\mu \mathrm{g} / \mathrm{L}$, micrograms per liter; (32106), USGS National Water Information System parameter code; <, less than]

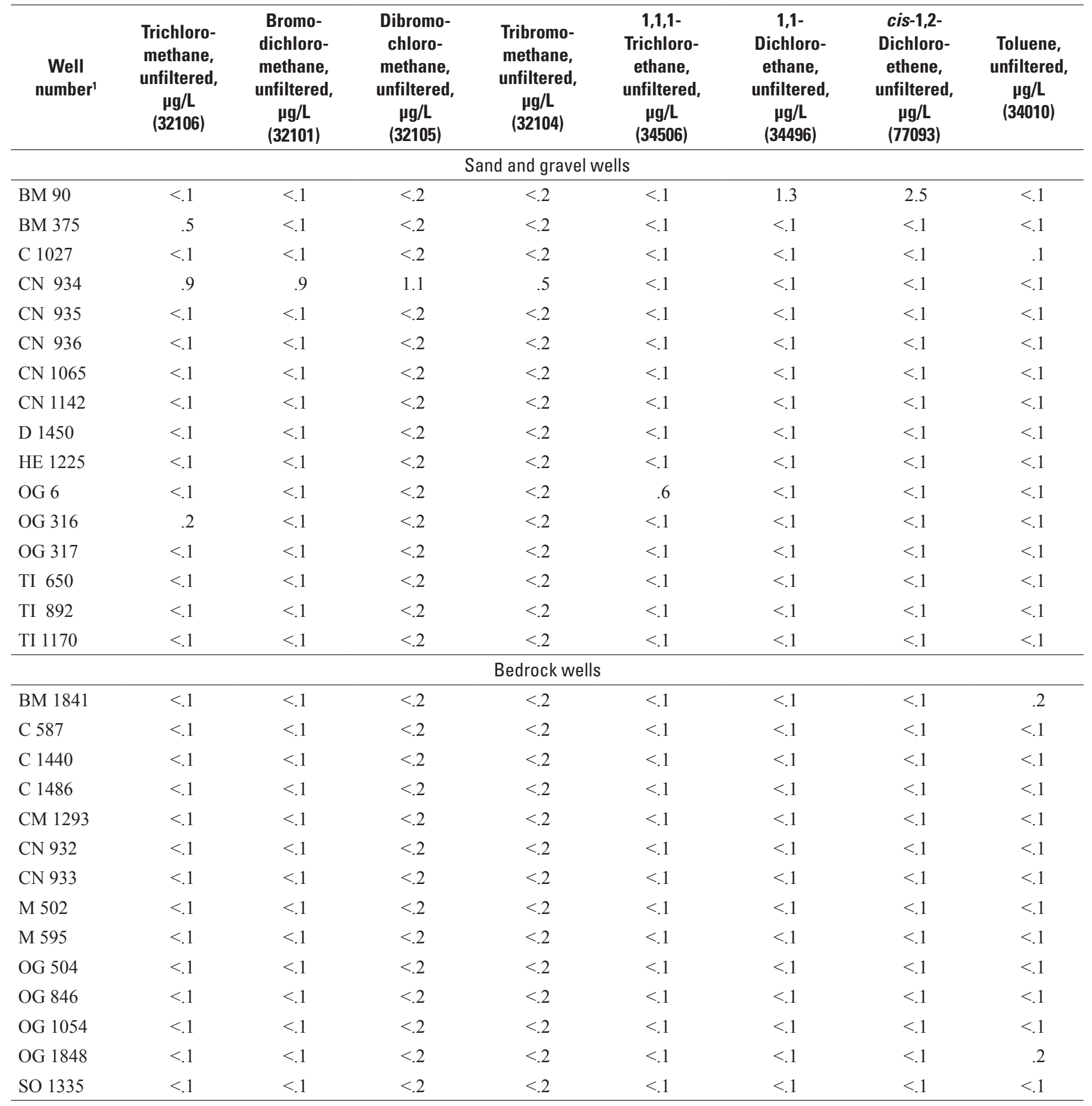

${ }^{1}$ Prefix denotes county: BM, Broome; C, Cortland; CM, Chemung; CN, Chenango; D, Delaware; HE, Herkimer; M, Madison; OG, Otsego; SO, Schoharie; TI, Tioga. Number is local well-identification number assigned by U.S. Geological Survey. 
Table 1-9. Concentrations of bacteria in unfiltered groundwater samples from the Upper Susquehanna River Basin, New York, 2009.

[Well locations are shown in figure 1. mL, milliliter; (61213), National Water Information System (NWIS) parameter code; CFU, colony-forming unit; <, less than; >, greater than. Bold values exceed one or more drinking-water standard]

\begin{tabular}{|c|c|c|c|c|}
\hline $\begin{array}{c}\text { Well } \\
\text { number }^{1}\end{array}$ & $\begin{array}{c}\text { Total coliform } \\
\text { colonies per } 100 \mathrm{~mL} \\
(61213)\end{array}$ & $\begin{array}{c}\text { Fecal coliform } \\
\text { colonies per } 100 \mathrm{~mL} \\
(61215)\end{array}$ & $\begin{array}{c}\text { Escherichia coli, } \\
\text { colonies per } 100 \mathrm{~mL} \\
\text { (31691) }\end{array}$ & $\begin{array}{l}\text { Heterotrophic plate } \\
\text { count, } \\
\text { CFUs per mL } \\
\text { (31692) }\end{array}$ \\
\hline \multicolumn{5}{|c|}{ Sand and gravel wells } \\
\hline BM 90 & $<1$ & $<1$ & $<1$ & 7 \\
\hline BM 375 & 32 & $<1$ & $<1$ & 9 \\
\hline C 1027 & $<1$ & $<1$ & $<1$ & 7 \\
\hline CN 934 & $<1$ & $<1$ & $<1$ & 1 \\
\hline CN 935 & $<1$ & $<1$ & $<1$ & $<1$ \\
\hline CN 936 & $<1$ & $<1$ & $<1$ & 1 \\
\hline CN 1065 & $<1$ & $<1$ & $<1$ & 24 \\
\hline CN 1142 & $<1$ & $<1$ & $<1$ & $<1$ \\
\hline D 1450 & $<1$ & $<1$ & $<1$ & 2 \\
\hline HE 1225 & $<1$ & $<1$ & $<1$ & 1 \\
\hline OG 6 & $<1$ & $<1$ & $<1$ & 1 \\
\hline OG 316 & $<1$ & $<1$ & $<1$ & 3 \\
\hline OG 317 & $>\mathbf{2 0 0}$ & $<1$ & $<1$ & 5 \\
\hline TI 650 & $<1$ & $<1$ & $<1$ & 1 \\
\hline TI 892 & $<1$ & $<1$ & $<1$ & 7 \\
\hline TI 1170 & $<1$ & $<1$ & $<1$ & 29 \\
\hline \multicolumn{5}{|l|}{ Bedrock wells } \\
\hline BM 1841 & $<1$ & $<1$ & $<1$ & 6 \\
\hline C 587 & $<1$ & $<1$ & $<1$ & 2 \\
\hline C 1440 & $<1$ & $<1$ & $<1$ & 46 \\
\hline C 1486 & $<1$ & $<1$ & $<1$ & 3 \\
\hline CM 1293 & $<1$ & $<1$ & $<1$ & 27 \\
\hline CN 932 & 4 & $<1$ & $<1$ & 2 \\
\hline CN 933 & $<1$ & $<1$ & $<1$ & 1 \\
\hline M 502 & 4 & 1 & $<1$ & 1 \\
\hline M 595 & 27 & $<1$ & $<1$ & 6 \\
\hline OG 504 & $<1$ & $<1$ & $<1$ & 3 \\
\hline OG 846 & 9 & $<1$ & $<1$ & 566 \\
\hline OG 1054 & 8 & 1 & 2 & 24 \\
\hline OG 1848 & 10 & $<1$ & $<1$ & 12 \\
\hline SO 1335 & 88 & $<1$ & $<1$ & 16 \\
\hline
\end{tabular}

${ }^{1}$ Prefix denotes county: BM, Broome; C, Cortland; CM, Chemung; CN, Chenango; D, Delaware; HE, Herkimer; M, Madison; OG, Otsego; SO, Schoharie; TI, Tioga. Number is local well-identification number assigned by U.S. Geological Survey. 


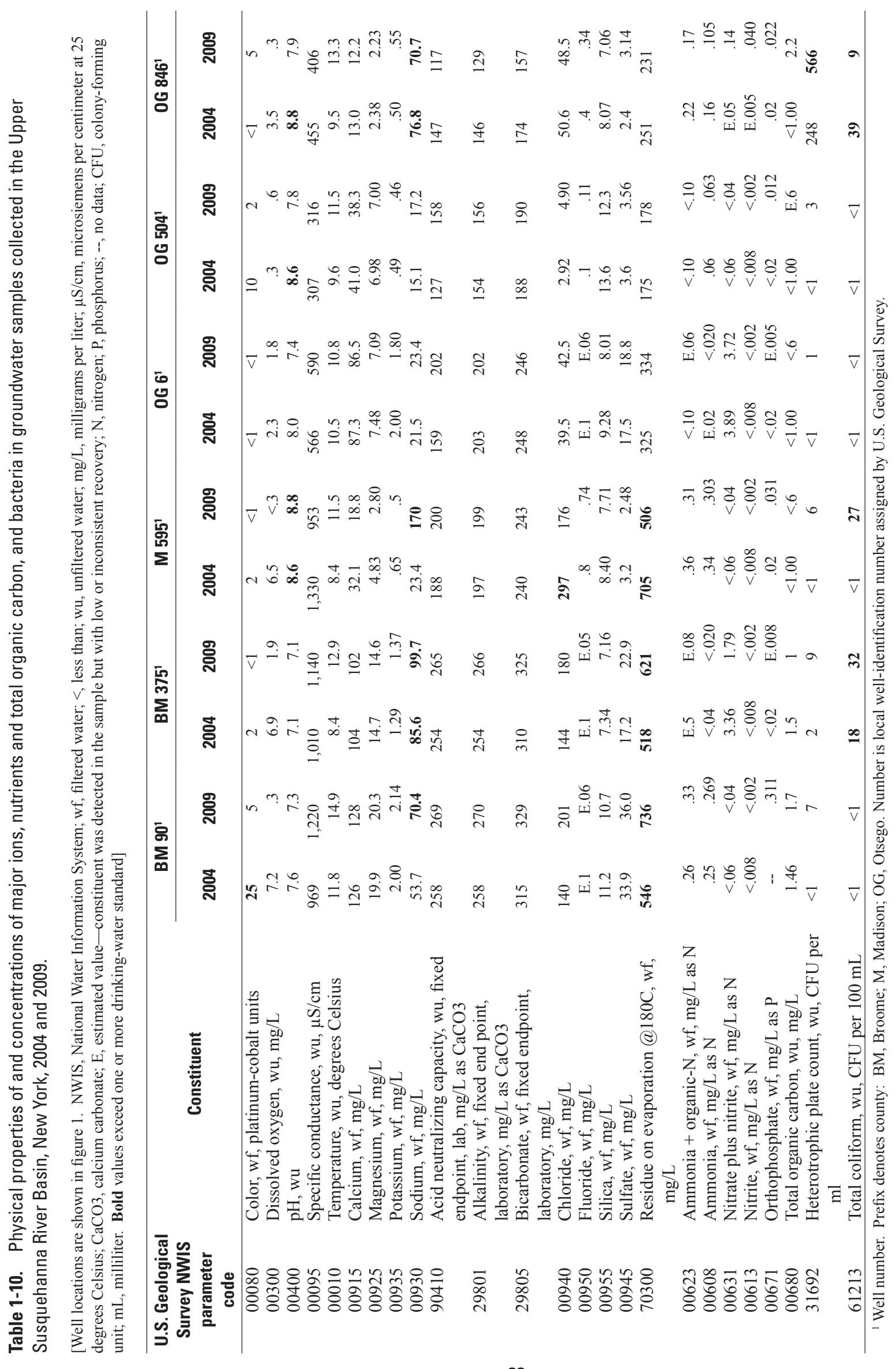




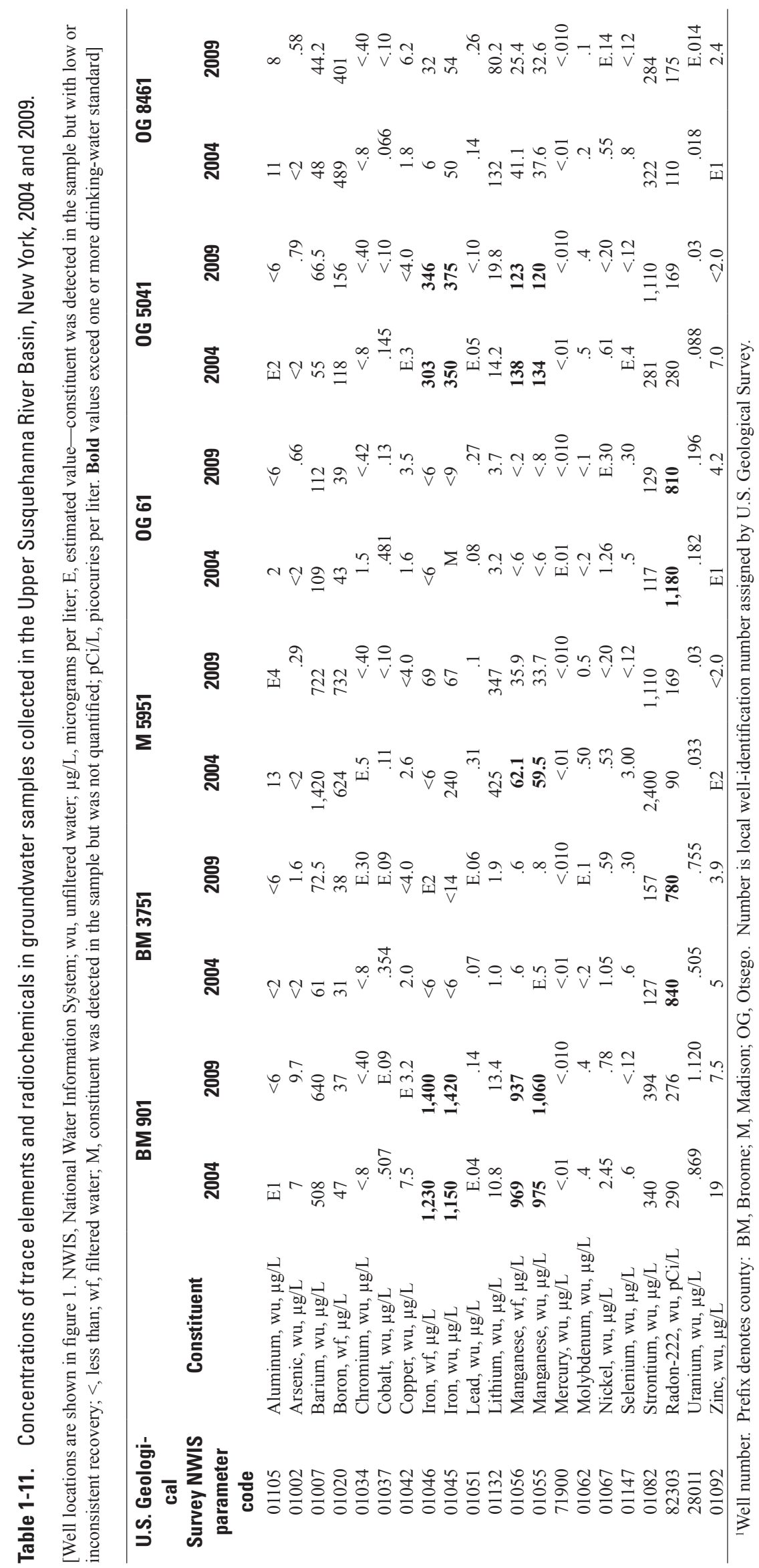



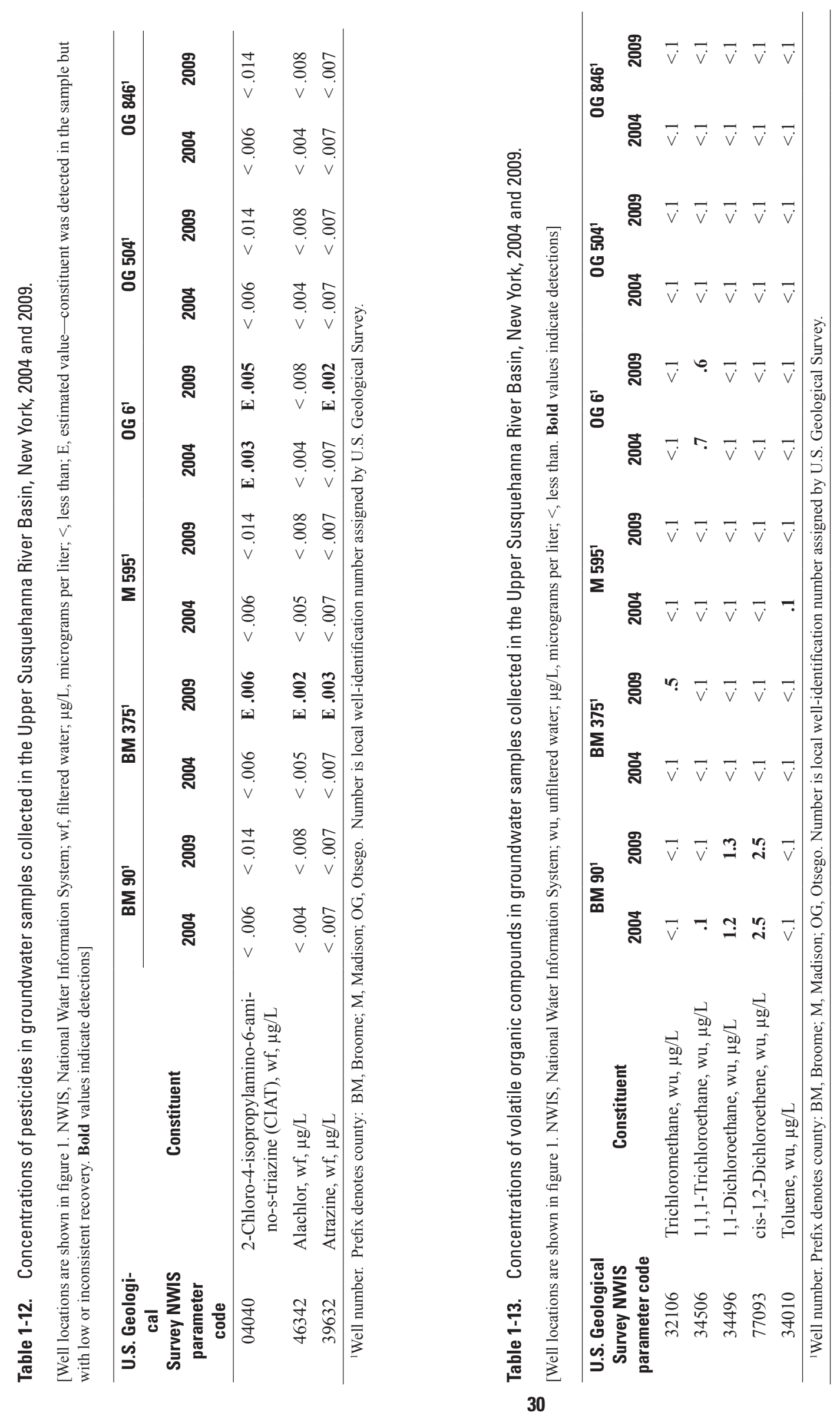
Prepared by the Pembroke and Rolla Publishing Service Centers

For additional information write to:

New York Water Science Center

U.S. Geological Survey

30 Brown Rd.

Ithaca, NY 14850

Information requests:

(518) 285-5602

or visit our Web site at: http://ny.water.usgs.gov 


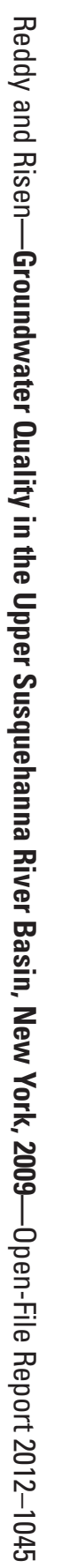

